\title{
Global and regional phosphorus budgets in agricultural systems and their implications for phosphorus-use efficiency
}

\author{
Fei Lun ${ }^{1}$, Junguo Liu ${ }^{2}$, Philippe Ciais ${ }^{3}$, Thomas Nesme ${ }^{4}$, Jinfeng Chang ${ }^{3}$, Rong Wang ${ }^{3}$, Daniel Goll ${ }^{3}$, \\ Jordi Sardans $^{5}$, Josep Peñuelas ${ }^{6}$, and Michael Obersteiner ${ }^{7}$ \\ ${ }^{1}$ College of Resources and Environmental Sciences, China Agricultural University, Beijing 100193, China \\ ${ }^{2}$ School of Environmental Science and Engineering, South University of Science and Technology \\ of China, Shenzhen 518055, China \\ ${ }^{3}$ IPSL - LSCE, CEA CNRS UVSQ, Centre d'Etudes Orme des Merisiers, 91191 Gif-sur-Yvette, France \\ ${ }^{4}$ Bordeaux Sciences Agro, Université de Bordeaux, UMR 1391 ISPA, CS 40201, \\ 33175 Gradignan CEDEX, France \\ ${ }^{5}$ CREAF, Cerdanyola del Vallès 08193, Catalonia, Spain \\ ${ }^{6}$ CSIC, Global Ecology Unit CREAF-CSIC-UAB, Cerdanyola del Vallès 08193, Catalonia, Spain \\ ${ }^{7}$ International Institute for Applied Systems Analysis, 2361 Laxenburg, Austria \\ Correspondence: Junguo Liu (liujg@ sustc.edu.cn, junguo.liu@gmail.com)
}

Received: 16 May 2017 - Discussion started: 6 June 2017

Revised: 31 October 2017 - Accepted: 21 November 2017 - Published: 8 January 2018

\begin{abstract}
The application of phosphorus (P) fertilizer to agricultural soils increased by $3.2 \%$ annually from 2002 to 2010. We quantified in detail the P inputs and outputs of cropland and pasture and the $\mathrm{P}$ fluxes through human and livestock consumers of agricultural products on global, regional, and national scales from 2002 to 2010. Globally, half of the total $P$ inputs into agricultural systems accumulated in agricultural soils during this period, with the rest lost to bodies of water through complex flows. Global $\mathrm{P}$ accumulation in agricultural soil increased from 2002 to 2010 despite decreases in 2008 and 2009, and the P accumulation occurred primarily in cropland. Despite the global increase in soil P, $32 \%$ of the world's cropland and $43 \%$ of the pasture had soil $\mathrm{P}$ deficits. Increasing soil P deficits were found for African cropland vs. increasing $\mathrm{P}$ accumulation in eastern Asia. European and North American pasture had a soil $\mathrm{P}$ deficit because the continuous removal of biomass $\mathrm{P}$ by grazing exceeded $\mathrm{P}$ inputs. International trade played a significant role in $\mathrm{P}$ redistribution among countries through the flows of $\mathrm{P}$ in fertilizer and food among countries. Based on country-scale budgets and trends we propose policy options to potentially mitigate regional $\mathrm{P}$ imbalances in agricultural soils, particularly by optimizing the use of phosphate fertilizer and the recycling of waste $\mathrm{P}$. The trend of the increasing consumption of livestock products will require more $\mathrm{P}$ inputs to the agricultural system, implying a low P-use efficiency and aggravating P-stock scarcity in the future. The global and regional phosphorus budgets and their PUEs in agricultural systems are publicly available at https://doi.pangaea.de/10.1594/PANGAEA.875296.
\end{abstract}




\section{Introduction}

Population increases and dietary changes require higher food production, which increases global demand for fertilizers (Grote et al., 2005; Foley et al., 2011). Phosphorus (P) is an essential element for all organisms, and a lack of $\mathrm{P}$ limits growth. Fertilizer $\mathrm{P}$ enhances agricultural production, but $\mathrm{P}$ is also fixed in soils and can accumulate. In countries with high fertilizer use, much $\mathrm{P}$ is lost to leaching and run-off, leading to the eutrophication of both inland and coastal waters (Carpenter et al., 1998; MacDonald et al., 2011).

To supply the growing need for $\mathrm{P}$ in fertilizer, the mining of phosphate rock has quadrupled in the past half century, increasing from $46 \mathrm{Mt}$ in 1961 to $198 \mathrm{Mt}$ in 2011 (Scholz et al., 2013). Despite some short-term fluctuations in the price of phosphate rock, the global production of fertilizer $\mathrm{P}$ has been steadily increasing at a rate of 3 to $4 \%$ annually during the half century before 2011 and is projected to increase by 50 to $100 \%$ by 2050 (Cordell et al., 2009, 2012). Extractable phosphate rock is a non-renewable resource, and significant depletion of the resource is projected by the end of this century if the current intensive use continues, possibly leading to resource shortages (Cordell et al., 2009; van Vuuren et al., 2010; Peñuelas et al., 2013).

The mining of $\mathrm{P}$ and its application as fertilizer in cultivated land is a major anthropogenic perturbation of the natural biogeochemical P cycle (Carpenter and Bennett, 2011; Elser and Bennett, 2011; Steffen et al., 2015). The negative impacts of this perturbation on the natural environment depend on how much $\mathrm{P}$ is lost from regions with intensive fertilizer use (Smil, 2000; Bennett et al., 2001).

$\mathrm{P}$ application differs significantly between countries and crop types (Grote et al., 2005), and previous researchers have attempted to estimate the $\mathrm{P}$ flows in agricultural systems in Europe (Ott \& Rechberger, 2012), the United States (Suh \& Yee, 2011), China (Ma et al., 2011), France (Senthilkumar et al., 2012), Australia (Cordell et al., 2013), and the world (Smil, 2000; Liu et al., 2008; MacDonald et al., 2011; Schipanski \& Bennett, 2012). International trade and regional agricultural policies affect $\mathrm{P}$ budgets by increasing or decreasing the gap between $P$ inputs and $P$ outputs in agricultural land (Grote et al., 2005). Previous research mainly focused on cropland, and P fluxes in pasture and livestock production systems have also received more and more attention recently, especially due to diet change. The differences in methodologies, system boundaries, and data sources have made it difficult to assess the differences in the phosphorususe efficiencies (PUEs) among agricultural sectors and to extrapolate regional findings to the global scale.

To mitigate these problems, we (1) compiled a detailed and harmonized dataset of $\mathrm{P}$ fluxes in agriculture for countries around the world, including detailed analysis of input and output fluxes for cropland, managed grassland (hereafter, pasture), livestock, and human consumers of agricultural products; (2) characterized $\mathrm{P}$ budgets and P-use effi- ciencies in those different subsystems; and (3) examined how the international trade of phosphate fertilizer and agricultural commodities influences regional $\mathrm{P}$ fluxes. We performed this analysis on the scale of countries, regions, and the world; wherever possible, we distinguished different crop types. The study period was from 2002 to 2010 , allowing us to study temporal trends.

\section{Materials and methods}

In this study, we obtained data for 224 countries (Table S1 in the Supplement). We defined the agriculture system as cropland and pasture ecosystems plus human and livestock consumers of agricultural production and of other products containing P (Fig. 1). External P inputs to the agriculture system came from mined phosphate rock and atmospheric deposition. Several processes cause $\mathrm{P}$ losses from the system into the external environment (here, defined as non-agricultural land and bodies of water). Figure 1 presents the fluxes of $\mathrm{P}$ into and out of the agriculture system on a global scale, including internal fluxes between ecosystems and consumers. We quantified these fluxes in the present study based on a mass-balance approach (Cordell et al., 2012). We defined the phosphorus-use efficiency (PUE) of the agricultural system and of its subsystems as the ratio of the total $\mathrm{P}$ harvested in economic outputs (e.g. crops, meat, milk, and eggs) to the total P input. International trade in fertilizer and food is discussed separately in Sect. 2.3. The data sources and an overview of the mass-balance equations are presented in the rest of this section; details and equations are presented in the Supplement.

\subsection{P flows into and out of the agricultural system}

Inputs into the agricultural system, which are within the grey box in Fig. 1, are from mined phosphate rocks and atmospheric deposition. We did not include $\mathrm{P}$ from the in situ weathering of soil particles because the rate of this process is insignificant compared with the magnitude of other inputs (Liu et al., 2008). Outputs included P emission into the atmosphere from fires and $\mathrm{P}$ loss to uncultivated land or bodies of water.

\subsubsection{P inputs}

Data on agricultural inputs of phosphate $\mathrm{P}$ in fertilizers were collected from the International Fertilizer Industry Association (http://www.fertilizer.org) and divided between cropland and pasture uses based on information from FAO (2002) and the FAOSTAT database (http://www.fao.org/faostat/en/ \#data). A small fraction ( $8 \%$ ) of $\mathrm{P}$ from mined phosphate rock is used to produce animal feed additives. Apart from fertilizer and animal feed additives, the rest of the mined $\mathrm{P}$ is used to produce detergents and other products directly consumed by humans (Ringeval et al., 2014). Atmospheric 


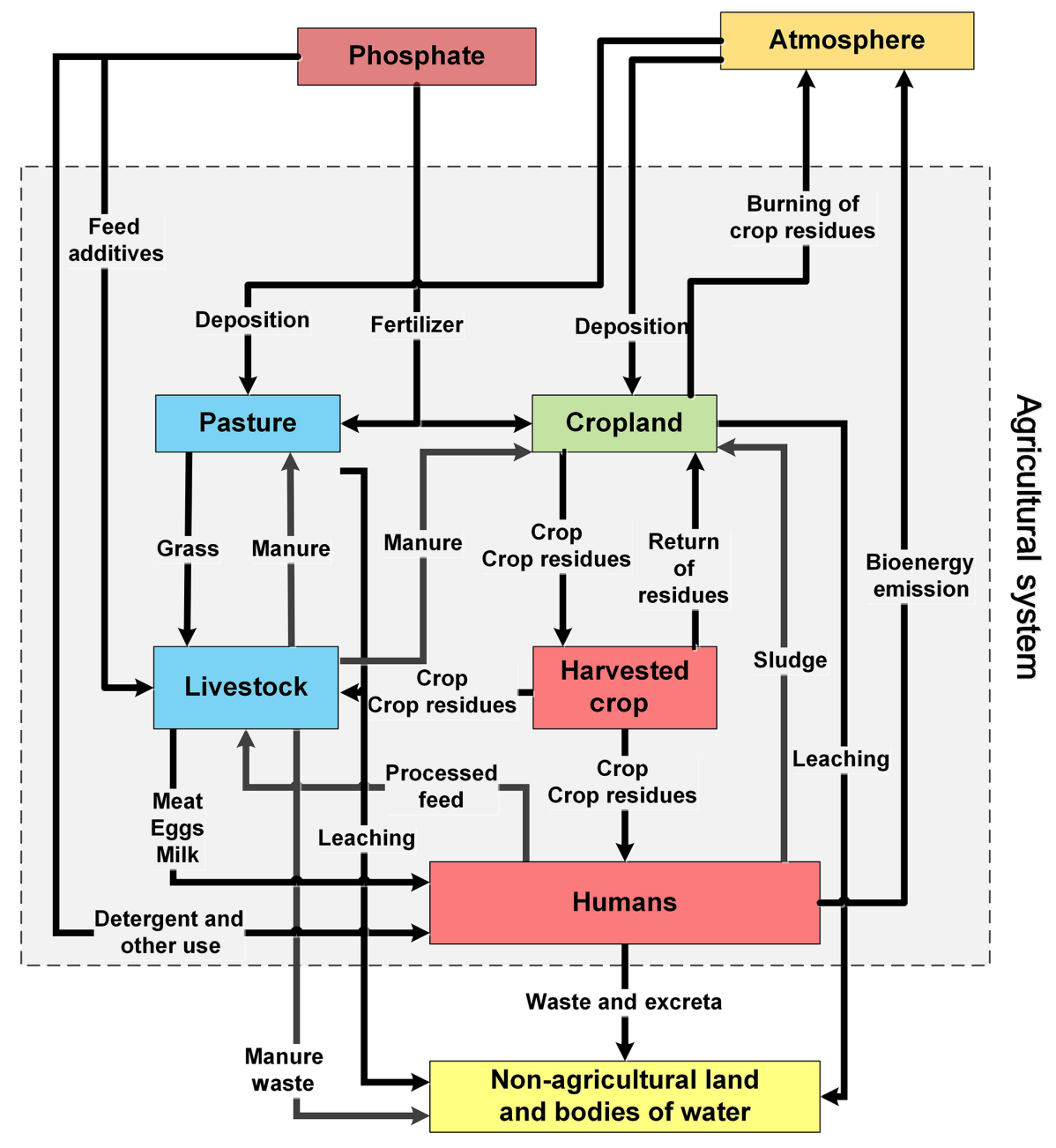

Figure 1. Scheme of the $\mathrm{P}$ pools and fluxes used to diagnose global $\mathrm{P}$ budgets for the agricultural sector. The agricultural sector (or system) in the grey box includes cropland and pasture soils, livestock, human consumers of livestock and crop products, and users of phosphate-derived products. National and regional $\mathrm{P}$ budgets are calculated using the same scheme, but including in addition exports and imports of $\mathrm{P}$ embedded in traded crop and livestock products and fertilizers.

$\mathrm{P}$ deposition in cropland and pasture areas was calculated separately in each country using gridded global P-deposition maps obtained using the LMDz-INCA aerosol chemistry transport model of Wang et al. $(2014,2015)$ and agricultural land-use maps. Details are provided in the Supplement (Table S2).

\subsubsection{P outputs}

$\mathrm{P}$ emissions from agricultural fires were obtained from the gridded dataset of Wang et al. (2015) and cover the burning of crop residues in the field, by households, and for the production of bioenergy from crop biomass. Leaching from cropland and pasture soils was assumed to be a constant fraction (12.5\%) of $\mathrm{P}$ inputs for each agricultural land-use type (Bouwman et al., 2013). P outputs from non-recycled livestock and human manure were calculated based on the mass balance. Note that erosion-induced losses of $\mathrm{P}$ are important in many agricultural regions (Quinton et al., 2010), but were not considered in this study because we lack data on the redeposition of $\mathrm{P}$ in eroded soil material from agricultural soils. In future studies, it will be important to quantify this source of $\mathrm{P}$, particularly in agricultural areas that receive large annual inputs of sediment (e.g. in river floodplains and sites on steep terrain that experience significant erosion farther up the slope followed by deposition).

\subsection{P flows within the agricultural system}

\subsection{1 $\mathrm{P}$ in harvested crop biomass and crop residues}

The flux of $\mathrm{P}$ in harvested crop biomass was estimated from yield data (FAOSTAT) using crop-specific P concentrations after grouping 178 different crops into 13 crop types (COMIFER, 2007; USDA-NRCS, 2009; Waller, 2010; 


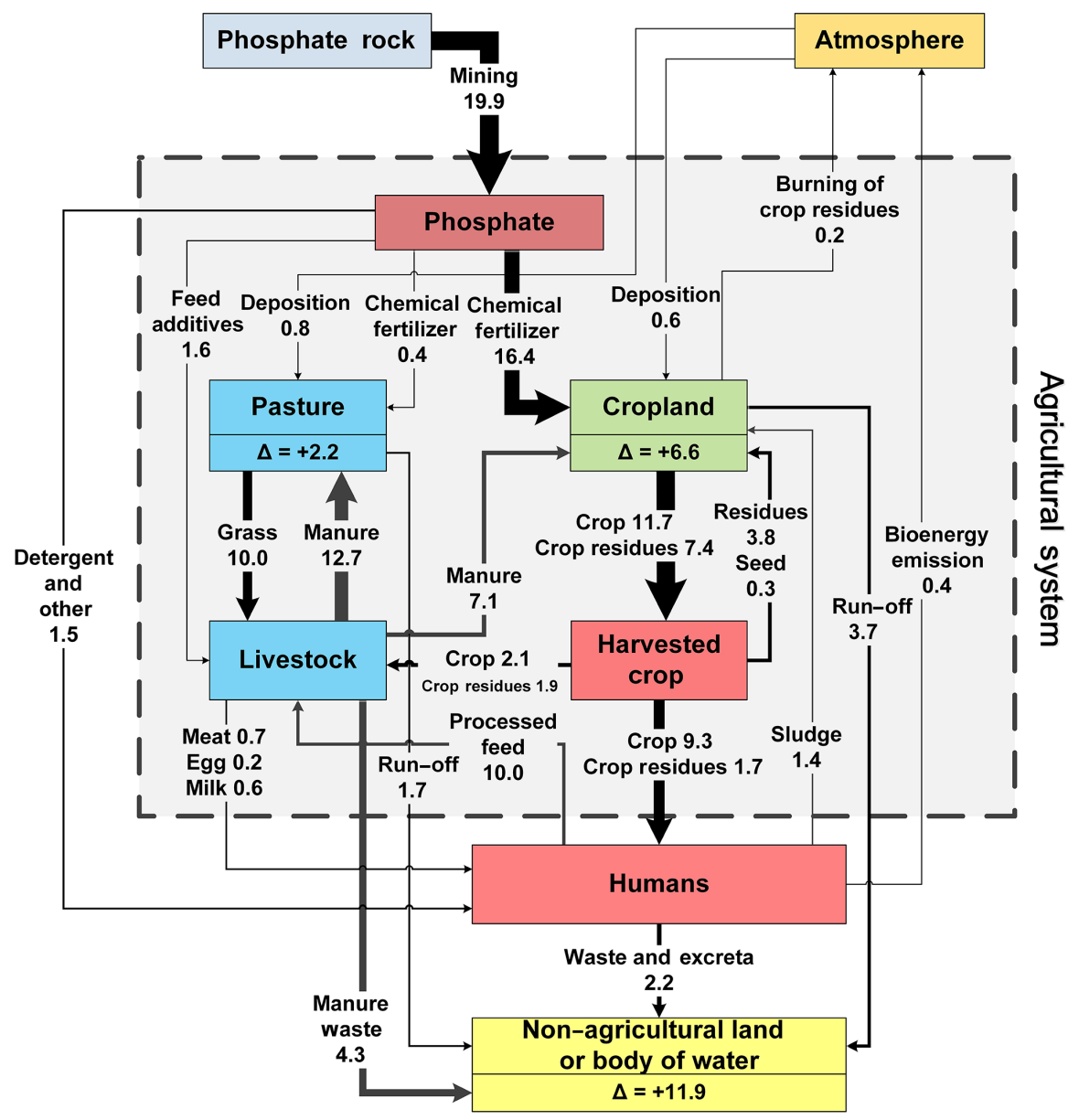

Figure 2. Annual $\mathrm{P}$ flows in the global agriculture system from 2002 to 2010 . Values are $\mathrm{Tg} \mathrm{P} \mathrm{yr}^{-1}$. The notation $\Delta$ denotes the average change of $\mathrm{P}$ in pasture and cropland soils, respectively. By convention, a positive value means accumulation. Note that livestock and human changes of $\mathrm{P}$ are assumed to be zero.

Table S2). P in harvested crop biomass was partitioned into crops (for human and livestock consumption) and crop residues (Fig. 1). We estimated the $\mathrm{P}$ fluxes of crop residues from FAOSTAT data and from Liu et al. (2008) to account for residue that is recycled in the field (50\%), transformed into livestock feed $(25 \%)$, and burned or used by other human activities $(25 \%)$.

\subsection{2 $\mathrm{P}$ in grazed biomass}

The $\mathrm{P}$ removed from pasture by livestock grazing was estimated by combining forage grass consumption data with the $\mathrm{P}$ concentrations in grass biomass (Antikainen et al., 2005; COMIFER, 2007; USDA-NRCS, 2009; Waller, 2010). Gridded data on grass biomass consumption by livestock were obtained by combining the global livestock production systems dataset of Herrero et al. (2013) with pasture net primary productivity simulated by the ORCHIDEE-GM global pasture model (Chang et al., 2013, 2015). We chose the ORCHIDEE-
GM model for this analysis because it is able to separate the intake of grazed vs. cut forage grass.

\subsection{3 $\mathrm{P}$ in animal feed products}

Animal feed products used as complementary diet ("feed additives") represent direct inputs to the livestock subsystem (Fig. 1). This flux was deduced from the mass balance of the known input and output fluxes for the livestock P pool, but did not account for long-term changes in $\mathrm{P}$ storage in that pool. See the Supplement for more details.

\subsubsection{P embedded in livestock products}

This flux of P leaving the livestock subsystem and entering the human subsystem (Fig. 1) through the harvesting of products was calculated by multiplying the FAOSTAT production data for meat, eggs, and milk by the product-specific $\mathrm{P}$ concentrations reported by Grote et al. (2005). 


\subsection{5 $P$ in livestock manure}

We calculated the manure $\mathrm{P}$ production based on FAOSTAT data about $\mathrm{N}$ in livestock manure and $\mathrm{P}: \mathrm{N}$ values for each types of livestock manure (MWPS-18, 1985; OECD Secretariat, 1991; Levington Agriculture, 1997; Sheldrick et al., 2003; ASAE, 2005; see Table S3). Once produced, manure P is either applied to cropland, left in the pasture, or lost to the environment as waste (Fig. 1), following the same partitioning as that for $\mathrm{N}$ in the manure from FAOSTAT.

\subsection{6 $P$ in human sewage sludge}

We assumed that the $\mathrm{P}$ output from humans equaled the inputs from non-fertilizer P-ore products and the consumed crop and livestock products (Fig. 1) and used this to calculate the total $\mathrm{P}$ production in human excreta. $\mathrm{P}$ in human sewage sludge was estimated using population data and values of per capita production of $\mathrm{P}$ in excreta (Smil, 2000; Cordell et al., 2009). Following the method of Liu et al. (2008), we assumed that $30 \%$ of the excreta $\mathrm{P}$ from urban populations and $70 \%$ of $\mathrm{P}$ from rural populations were returned to cropland, either directly or after the treatment of sewage sludge, with the remaining $\mathrm{P}$ assumed to be lost to the environment (e.g. in landfills or bodies of water).

\subsection{P flows from international trade}

We compiled the flows of $\mathrm{P}$ in international trade both from the $\mathrm{P}$ embodied in crops and livestock products and in $\mathrm{P}$ embodied in fertilizers exchanged between countries. For agricultural commodities, we used FAOSTAT data that provided a matrix of commodities exchanged between countries and converted this data into $\mathrm{P}$ fluxes using commodity-specific $\mathrm{P}$ content data. For P fertilizers, we used the International Fertilizer Industry Association trade statistics. By convention, a positive trade balance for a country means that it is a net $\mathrm{P}$ importer. In addition, $\mathrm{P}$ fluxes associated with the international trade of fertilizers, food, feed, and fibre commodities can be associated with local cropland PUE and pasture PUE. We defined the dependency on chemical fertilizer imports $\left(F_{\text {fer }}\right)$ as the ratio of the $\mathrm{P}$ in imported chemical fertilizers $\left(P_{\text {fer-imp }}\right)$ to the $\mathrm{P}$ in all chemical fertilizers consumed by a country $\left(P_{\text {fer-con }}\right)$. Similarly, we defined the dependency on food imports $\left(F_{\text {food }}\right)$ as the ratio of $\mathrm{P}$ in food imports ( $\left.P_{\text {food-imp }}\right)$ to the $\mathrm{P}$ in all food consumed by a country. Furthermore, we defined $F_{\text {total }}$ as the ratio of the total $\mathrm{P}$ imported (food and fertilizers) to the total $\mathrm{P}$ consumed as fertilizers and food in a country. The equations for these calculations are presented in Sects. 2 to 6 of the Supplement.

\subsection{Annual P budgets of cropland and pasture soils}

Annual changes in $\mathrm{P}$ stocks in cropland and pasture soils $(\Delta P)$ were estimated as the difference between inputs and outputs (i.e. the budget); $\Delta P>0$ indicates net $\mathrm{P}$ accumulation in the soil, $\Delta P<0$ indicates a net deficit, and $\Delta P=0$ represents no net change. $\Delta P$ calculated in this manner does not reflect the legacy effects from previous management and fertilization practices (Ringeval et al., 2014), but it is a useful metric to identify regions with a $\mathrm{P}$ surplus or deficit at any point in time and to compare countries.

Annual soil $\Delta P$ values were calculated as the differences between annual inputs and outputs. Details and the equations are presented in Sect. 2 of the Supplement.

\subsection{Cumulative P budgets of cropland and pasture soils}

Following the method of Sattari et al. (2012), we separated the $\mathrm{P}$ inputs to soils (except inputs in seeds) into two pools: (1) a stable P pool, which represents $\mathrm{P}$ that is unavailable to plants on an annual basis, such as the $\mathrm{P}$ absorbed onto iron and aluminum oxides $(20 \%$ of total $\mathrm{P}$ inputs, including fertilizers, manure, sludge, and deposition); and (2) a labile $\mathrm{P}$ pool that is assumed to be available for plant uptake $(80 \%$ of total $\mathrm{P}$ inputs). $\mathrm{P}$ can be exchanged between the two pools. If inputs of labile $\mathrm{P}$ are larger than $\mathrm{P}$ removal in crop biomass, we assumed that the surplus labile $P$ gets transferred into the stable $\mathrm{P}$ pool at the end of the year. In the opposite case, in which inputs of labile $\mathrm{P}$ are lower than $\mathrm{P}$ removal, plants can take up P from the stable pool (Sattari et al., 2012). This approach assumes that the $\mathrm{P}$ loss by run-off and leaching into bodies of water is from the labile $\mathrm{P}$ pool only and that $\mathrm{P}$ stored in seeds does not belong to either the stable pool or the labile pool. This approach is simplistic, as more research will be required to allow for more realistic modelling of these two pools and the flows they are involved in.

\subsection{Phosphorus-use efficiency}

We defined PUE as the ratio of $\mathrm{P}$ in the harvested economic outputs to $\mathrm{P}$ in the inputs for the entire agricultural system (the grey area in Fig. 1) or for a given subsystem. PUE indicates how much of the input $\mathrm{P}$ is transferred into valueadded products. If $\mathrm{PUE}>1$, the input of $\mathrm{P}$ is insufficient to sustain the output (harvested $\mathrm{P}$ ), suggesting a net reduction of the system's $P$ reservoir. For cropland PUE, we defined $\mathrm{P}$ in harvested crops as the economic $\mathrm{P}$ output of the crops and the sum of phosphate fertilizer, livestock manure, human sewage sludge, and $\mathrm{P}$ from atmospheric deposition as the $\mathrm{P}$ input. For pasture PUE, harvested $\mathrm{P}$ refers to the $\mathrm{P}$ consumed by grazing animals and the sum of phosphate fertilizer, livestock manure going to the pasture, and $\mathrm{P}$ from atmospheric deposition as the total inputs. For the livestock subsystem, the harvested $\mathrm{P}$ output represents the $\mathrm{P}$ in livestock products (meat, eggs, and milk), whereas the inputs represent the input into livestock. We also defined the PUE of human food ( $\varepsilon_{\text {food }}$ ) as the ratio of the $\mathrm{P}$ content in human excreta to the total $\mathrm{P}$ input in human food; this represents an inconsistency with our previous definitions, since human excreta currently 
have no economic value. The equations for all the PUE terms are provided in Sect. 5 of the Supplement.

\subsection{Uncertainty estimates}

Uncertainties in each flux originate both from the material flux data and from data on the $\mathrm{P}$ concentration in each material considered by our analysis, including crop products, crop residues, livestock, meat, eggs, milk, livestock, and human excreta. Many of the global statistical datasets used in our analysis are not replicated, and no alternative dataset is available for establishing a range of uncertainty values for the different $P$ fluxes. National datasets have usually not been formally analysed to determine their uncertainty, and many of the sources of uncertainty are difficult to trace (e.g. clerical errors, differences between countries in product definitions). Thus, we have only addressed the effect of uncertainties in the $\mathrm{P}$ concentration by means of Monte Carlo simulations (3000 iterations) using the range of $\mathrm{P}$ concentrations reported in the literature (Table S5).

\section{Results}

\subsection{Global agricultural P flows and their trends}

\subsubsection{Global P fluxes in and out of the agricultural system}

Figure 2 summarizes the annual average of global $\mathrm{P}$ flows for the period from 2002 to 2010. P from phosphate fertilizers was the largest single input flux, representing $93 \%$ of the $21.3 \mathrm{TgPyr}^{-1}$ of global input, and most of it $(82.4 \%)$ goes to cropland and pasture. Outputs from the agriculture system amounted to $12.5 \mathrm{Tg} \mathrm{Pyr}^{-1}$, which combines outputs from leaching and run-off into bodies of water (5.4), nonrecycled manure waste (4.3), and sewage (2.2), bioenergy (0.4), and burned crop residues (0.2). The global annual $\mathrm{P}$ balance of agricultural systems was therefore positive during the entire study period, with $8.8 \mathrm{TgPyr}^{-1}$ accumulating in soil, of which $6.6 \mathrm{Tg} \mathrm{Pyr}^{-1}$ accumulated in cropland and 2.2 $\mathrm{TgPyr}^{-1}$ in pasture. On average, $41 \%$ of the $\mathrm{P}$ input accumulated in soils from 2002 to 2010.

\subsubsection{Temporal trends}

Figure 3 shows the trends for the four largest $\mathrm{P}$ fluxes in the agriculture system, illustrating that chemical fertilizer inputs, $\mathrm{P}$ loss to the environment, and $\mathrm{P}$ harvested in crops presented significantly increasing trends during this period. The application of phosphate fertilizer increased at an average annual rate of $3.2 \%$ from 2002 to 2010 despite a decrease in 2008 that reflected reduced fertilizer application at a time when the price of phosphate fertilizers increased (Cordell et al., 2009, 2012). The trend for $P$ in harvested crop biomass was also a steady increase, but at a lower annual rate $(2.4 \%)$ and with no decrease in 2008, probably because of the availability of

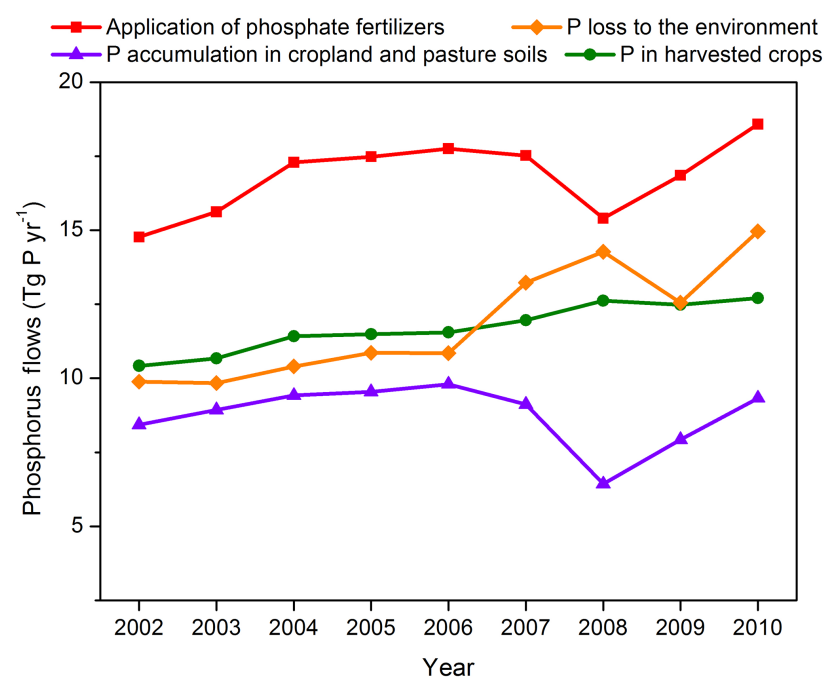

Figure 3. Time series in the four largest global annual $\mathrm{P}$ flows within, in, and out of the agriculture system from 2002 to 2010.

$\mathrm{P}$ that accumulated in the soil from previous years (as described in Sect. 2.5). Overall, $\mathrm{P}$ in agricultural soils increased by $1.3 \%$ annually, whereas $\mathrm{P}$ losses to the environment increased faster $\left(6.4 \% \mathrm{yr}^{-1}\right)$ than fertilizer inputs.

\subsubsection{Global P fluxes in cropland}

Cropland received the largest fraction $(82 \%)$ of phosphate fertilizer, $29 \%$ of the manure produced by livestock, and all of the recycled human sewage sludge (Fig. 2). Atmospheric deposition contributed an additional $0.6 \mathrm{Tg} \mathrm{Pyr}^{-1}$ of inputs to croplands. Harvesting of cropland removed 11.7 $\mathrm{Tg} \mathrm{Pyr}^{-1}$, which can be divided into crop products used for human nutrition (9.3 ${\mathrm{TgP} \mathrm{Pr}^{-1}}^{-1}$, including 5.3 for food, 2.7 for processing, 0.4 for waste, and 0.9 for other use) and for livestock feed $\left(2.1 \mathrm{TgPyr}^{-1}\right)$, with a small pool in seeds returned to the cropland $\left(0.3 \mathrm{TgPyr}^{-1}\right)$. On average, $50 \%$ of the $\mathrm{P}$ contained in crop residues was recycled to cropland during the study period, with $0.2 \mathrm{TgPyr}^{-1}$ lost to the atmosphere from the burning of crop residues. The remaining 3.6 $\mathrm{TgPyr}^{-1}$ contained in harvested crop residues is removed from cropland and redistributed to livestock and humans. Globally, 3.7 $\mathrm{TgP}_{\mathrm{yr}}{ }^{-1}$ was lost from cropland soils through leaching and run-off. The sum of all these fluxes results in an annual soil $\mathrm{P}$ accumulation of $6.6 \mathrm{TgP}_{\mathrm{yr}}{ }^{-1}$ (Fig. 2).

The global cropland PUE averaged 0.46 , with a maximum of 0.51 in 2008 and a minimum of 0.44 in 2006. The annual cropland $\mathrm{P}$ accumulation ratio (cropland soil $\mathrm{P}$ accumulation / total P input to cropland) was $23 \%$, which is lower than the accumulation ratio of $48 \%$ found for the overall agriculture system. In countries where labile P inputs were lower than $\mathrm{P}$ removal in crops, the soil's labile $\mathrm{P}$ pool was depleted by $1.9 \mathrm{TgPyr}^{-1}$ through the harvesting of crop biomass. In countries where labile $\mathrm{P}$ inputs are higher than $\mathrm{P}$ removal by 


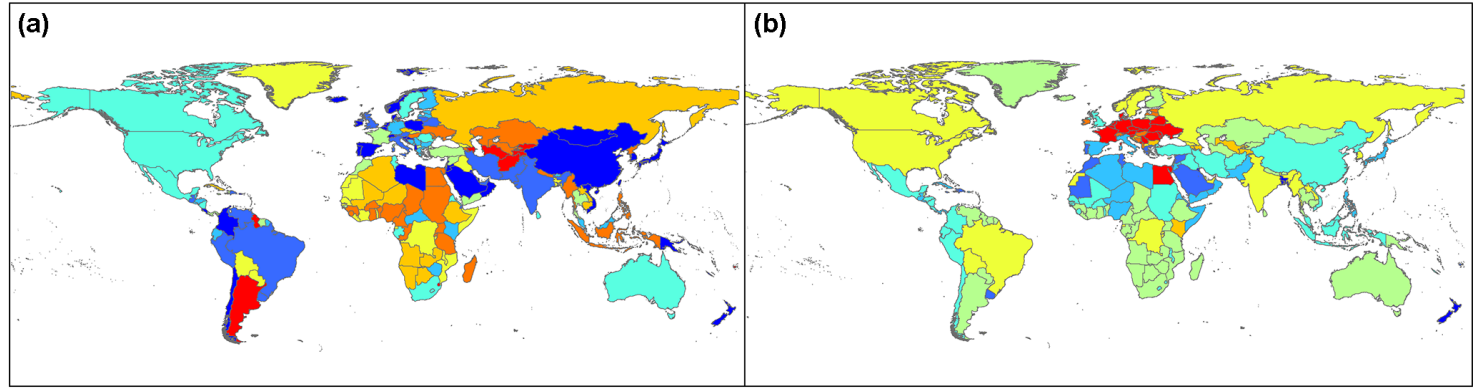

Net soil $P$ budget

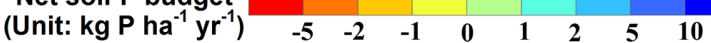

Figure 4. Map of global net soil P budgets (positive values, increase; negative values, decrease) for (a) cropland and (b) pasture.

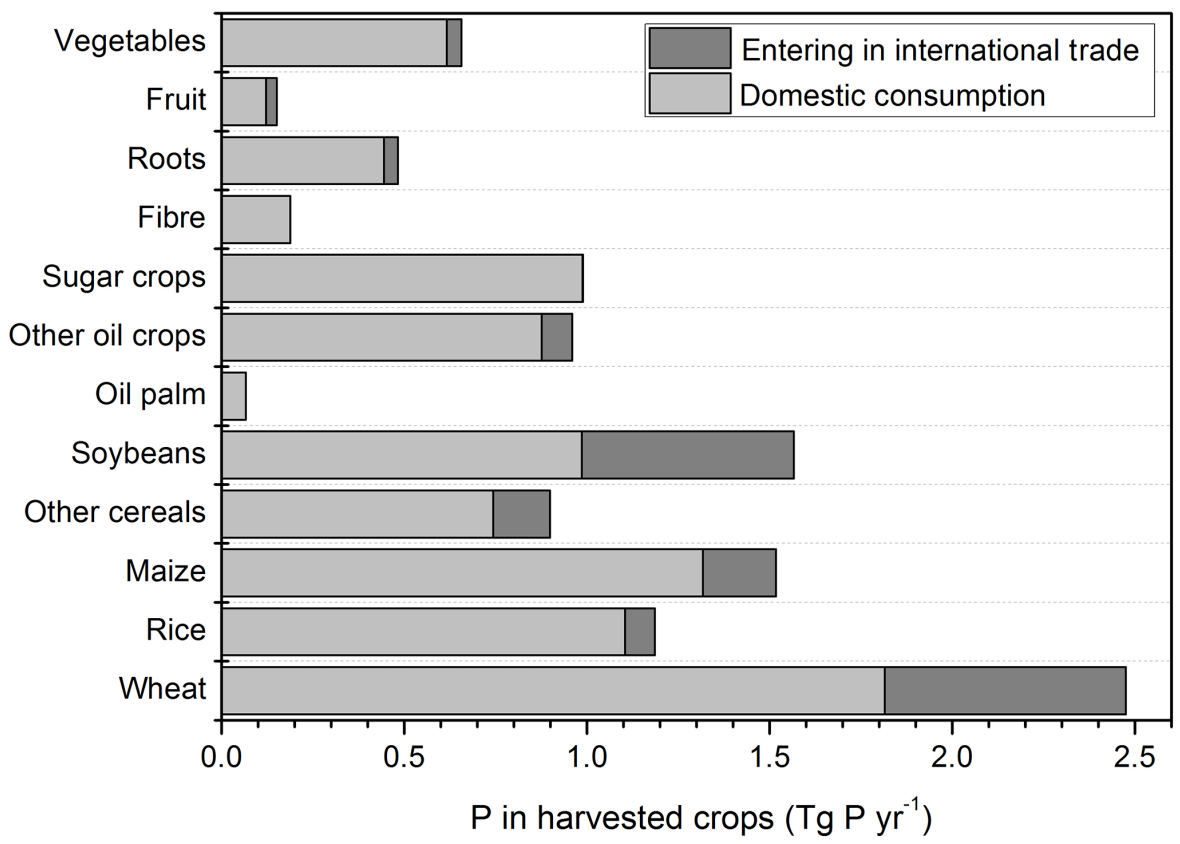

Figure 5. P flows embedded in different crop products, including the fraction of these flows entering into international trade circuits vs. being used for domestic consumption, for the year 2010 .

crops, the accumulation of soil labile $\mathrm{P}$ was $6.0 \mathrm{TgPyr}^{-1}$. Thus, there is an asymmetry between these two groups of countries, with accumulation being larger than depletion on a global scale. In addition, the global stable $\mathrm{P}$ pool in cropland increased by an average of $5.6 \mathrm{Tg} \mathrm{Pyr}^{-1}$ from 2002 to 2010.

\subsubsection{Global P fluxes in pasture}

Different from croplands, most $\mathrm{P}$ inputs to pasture were from livestock manure (12.7 $\mathrm{Tg} \mathrm{Pyr}^{-1}$ ), with small additional contributions from atmospheric deposition $\left(0.8 \mathrm{Tg} \mathrm{Pyr}^{-1}\right)$ and phosphate fertilizers $\left(0.4 \mathrm{Tg} \mathrm{Pyr}^{-1}\right)$. The primary production of pasture incorporates $10.0 \mathrm{Tg} \mathrm{Pyr}^{-1}$ of $\mathrm{P}$ into grass biomass that is digested by animals, and the leaching and run-off loss averages $1.7 \mathrm{TgPyr}^{-1}$. From all these fluxes, we estimated a global pasture PUE of 0.72 and a net accumulation of $2.2 \mathrm{TgPyr}^{-1}$ in the soil. In the countries where grass $\mathrm{P}$ removal exceeded the labile $\mathrm{P}$ inputs, the labile soil $\mathrm{P}$ pool was depleted by $1.4 \mathrm{Tg} \mathrm{Pyr}^{-1}$. In the countries where the labile $\mathrm{P}$ input exceeded grass $\mathrm{P}$ removal, an average of $5.3 \mathrm{Tg} \mathrm{Pyr}^{-1}$ was transferred from the labile to the stable soil $\mathrm{P}$ pool from 2002 to 2010.

\subsubsection{Global P fluxes in livestock}

The annual $\mathrm{P}$ input to livestock was $25.6 \mathrm{Tg} \mathrm{Pyr}^{-1}$, with most of the contributions from grazed grass $\left(10.0 \mathrm{TgPyr}^{-1}\right)$ and processed feed $\left(10.0 \mathrm{TgPyr}^{-1}\right)$. The economic $\mathrm{P}$ output in the form of livestock products averaged $1.5 \mathrm{Tg} \mathrm{Pyr}^{-1}$, which 
gives a PUE of 0.06 . Averages of 29 and $56 \%$ of the P produced in livestock manure were recycled into cropland and pasture, respectively; the rest of this manure $\left(4.3 \mathrm{TgPyr}^{-1}\right)$ was lost to the environment.

\subsubsection{Global P fluxes in human use}

Humans receive an annual input of $14.0 \mathrm{Tg} \mathrm{Pyr}^{-1}$ from harvested crop products, livestock products, and the use of detergents and other products manufactured from phosphate rock. Although P inputs as food (crop food and livestock products) amounted to $6.8 \mathrm{Tg} \mathrm{Pyr}^{-1}$, humans only absorbed 3.0 $\mathrm{Tg} \mathrm{Pyr}^{-1}$ (44\%); the remainder was either wasted before consumption (e.g. in food processing) or transferred back to livestock as processed feed. Thus, only $14.3 \%$ of the total $\mathrm{P}$ inputs into the agriculture system end up as food being actually consumed by humans. P lost to the environment by human use amounts to $2.6 \mathrm{Tg} \mathrm{Pyr}^{-1}$, which is divided among $2.2 \mathrm{Tg} \mathrm{Pyr}^{-1}$ lost through inefficient processing and excreta and $0.4 \mathrm{TgPyr}^{-1}$ through bioenergy-related emissions. The fate of non-recycled $\mathrm{P}$ in human waste was not separated between bodies of water (untreated sewage) and landfills.

\subsection{Regional P budgets}

Globally, both cropland and pasture presented soil P accumulation from 2002 to 2010, with an accumulation of 59.6 and 19.4 TgP, respectively. For croplands, the net $\mathrm{P}$ accumulation in the stable $\mathrm{P}$ pools amounted to $52.7 \mathrm{Tg} \mathrm{P}$, and the remaining $6.9 \mathrm{Tg} \mathrm{P}$ accumulated in soil labile pools. For pasture, the accumulation in the stable $\mathrm{P}$ pool was $25.0 \mathrm{Tg} \mathrm{P}$, but 5.6 Tg P was transferred from the stable $\mathrm{P}$ pool to be incorporated by grass in regions where $\mathrm{P}$ inputs are lower than grass $\mathrm{P}$ uptake.

Those global numbers mask large regional differences (Table 1 and Fig. 4) and there were also differences between cropland and grassland. About $32 \%$ of the global cropland area (in 75 countries) had annual soil P deficits from 2002 to 2007 , with a net cropland soil $\mathrm{P}$ accumulation of 6.20 7.66 $\mathrm{Tg} \mathrm{Pyr}^{-1}$. This fraction increased to $50 \%$ in 2008 and 2009 but the net cropland soil P accumulation decreased to $4.38 \mathrm{Tg} \mathrm{Pyr}^{-1}$ in 2008 and $5.39 \mathrm{Tg} \mathrm{Pyr}^{-1}$ at the time of the global financial crisis as a result of high $\mathrm{P}$ prices and the resulting reduction in fertilizer application (Cordell et al., 2009, 2012). However, the fraction of cropland soil $P$ deficits returned close to the decadal mean value in 2010, with a net soil $\mathrm{P}$ accumulation of $7.30 \mathrm{TgPyr}^{-1}$. On average, $48 \%$ of cropland $\mathrm{P}$ uptake was supplied by stable $\mathrm{P}$ that accumulated in previous years according to the equations in Sect. 3 of the Supplement. Including the United States, France, Russia, Argentina, and Paraguay, 89 countries had labile $\mathrm{P}$ inputs into cropland that were lower than crop P removal from 2002 to 2010 . However, if we consider stable P inputs, cropland soil still presented a net soil $\mathrm{P}$ surplus in the United States during the same period. Compared with cropland, a slightly larger proportion of the total global pasture area had a net annual soil P deficit from 2002 to 2010, mostly in Europe and North America. The deficit proportion of grassland was only about $38 \%$ in 2002 and 2003, with an annual net soil $\mathrm{P}$ accumulation of $2.26 \mathrm{Tg} \mathrm{Pyr}^{-1}$; however, it increased to $43 \%$ during the period of 2004-2010 and the annual pasture soil $\mathrm{P}$ accumulation was about $2.10 \mathrm{TgP}^{-1}$, with the smallest of $2.00 \mathrm{Tg} \mathrm{Pyr}^{-1}$ in 2009 . However, only 48 countries had labile $\mathrm{P}$ inputs into pasture that were lower than the $\mathrm{P}$ removal in grass.

\subsubsection{Regional cropland budgets}

Examining Fig. 4a reveals that cropland in all African countries experienced an annual soil $\mathrm{P}$ deficit, especially in western and central Africa, with soil $\mathrm{P}$ loss rates per unit area ranging from $2.5 \mathrm{~kg} \mathrm{Pha}^{-1} \mathrm{yr}^{-1}$ in 2002 to $2.7 \mathrm{~kg} \mathrm{Pha}^{-1} \mathrm{yr}^{-1}$ in 2010. In contrast, cropland in eastern Asia accumulated $23.4 \mathrm{~kg} \mathrm{Pha}^{-1} \mathrm{yr}^{-1}$ during the period from 2002 to 2010 , a cumulative storage equivalent to more than 4 years of $P$ fertilizer application. Cropland in Oceania, Europe, and the Caribbean and Central America also annually accumulated $\mathrm{P}$ in their soils. Cropland soils in North America and South America accumulated P from 2002 to 2007, but experienced temporary P deficits from 2008 to 2010 . Yet despite this, crop yields did not decrease from 2008 to 2010 in those two regions, probably because of the re-mobilization of $\mathrm{P}$ that accumulated in stable pools. Cropland soils in western and central Asia were nearly balanced, with a mean areal flux of $0.2 \mathrm{~kg} \mathrm{Pha}^{-1} \mathrm{yr}^{-1}$.

Considering the different countries (Fig. 4a), the largest cumulative soil $\mathrm{P}$ increase was found in China (34.6 Tg P) for the 9 years from 2002 to 2010, followed by India (11.4 TgP) and Brazil (3.6 TgP). Pakistan (1.8 TgP), the United States $(1.8 \mathrm{Tg} \mathrm{P})$, and New Zealand $(1.8 \mathrm{Tg} \mathrm{P})$ also had net soil $\mathrm{P}$ accumulation, yet of a smaller magnitude. These six countries accounted for $77 \%$ of the global accumulation of $\mathrm{P}$ in countries where cropland had a positive soil $\mathrm{P}$ balance. Furthermore, a large amount of $\mathrm{P}$ accumulated in the soil labile $P$ pools of cropland in China and India, at about 20.0 and 4.5 Tg P, respectively; however, in the United States, about 6.0 Tg P accumulated in the cropland stable $\mathrm{P}$ pool from 2002 to 2010; thus, $4.2 \mathrm{TgP}$ was absorbed from the previous cropland soil P. In contrast, most African countries experienced persistent cropland soil $\mathrm{P}$ deficits from 2002 to 2010. This was especially true in Nigeria, which had a cumulative deficit of $1.7 \mathrm{Tg}$ P (Fig. 4a). We also found cumulative soil P deficits in Russia, the Ukraine, and Kazakhstan, but with a smaller magnitude $(1.1,0.9$, and $0.7 \mathrm{Tg} \mathrm{P}$, respectively) for the 9 years. Comparing the rates of change of crop soil P per unit area, New Zealand had the fastest rate of increase $\left(>100 \mathrm{~kg} \mathrm{Pha}^{-1} \mathrm{yr}^{-1}\right)$, whereas Argentina had the fastest rate of decrease $\left(-7.9 \mathrm{~kg} \mathrm{Pha}^{-1} \mathrm{yr}^{-1}\right)$. In terms of the difference between inputs and outputs, loss rates in Argentina were about 5 times input rates. 
Table 1. Regional annual agricultural P budgets and P-use efficiency (PUE).

\begin{tabular}{|c|c|c|c|c|c|c|c|c|c|c|c|c|}
\hline Subsystem & World & $\begin{array}{r}\text { Eastern } \\
\text { and } \\
\text { southern } \\
\text { Africa }\end{array}$ & $\begin{array}{r}\text { Northern } \\
\text { Africa }\end{array}$ & $\begin{array}{r}\text { Western } \\
\text { and } \\
\text { central } \\
\text { Africa }\end{array}$ & $\begin{array}{r}\text { Eastern } \\
\text { Asia }\end{array}$ & $\begin{array}{r}\text { Southern } \\
\text { and south- } \\
\text { eastern } \\
\text { Asia }\end{array}$ & $\begin{array}{r}\text { Western } \\
\text { and } \\
\text { central } \\
\text { Asia }\end{array}$ & Oceania & Europe & $\begin{array}{r}\text { North } \\
\text { America }\end{array}$ & $\begin{array}{r}\text { Caribbean } \\
\text { and } \\
\text { Central } \\
\text { America }\end{array}$ & $\begin{array}{r}\text { South } \\
\text { America }\end{array}$ \\
\hline \multicolumn{13}{|c|}{ Agricultural land $\mathrm{P}$ budget $\left(\mathrm{TgPyr}^{-1}\right)^{\mathrm{a}}$} \\
\hline Cropland & 6.6 & -0.1 & -0.1 & -0.2 & 4.1 & 1.4 & 0.0 & 0.3 & 0.7 & 0.3 & 0.0 & 0.3 \\
\hline Pasture & 2.2 & 0.1 & 0.5 & 0.3 & 0.5 & 0.2 & 0.2 & 0.4 & -0.3 & -0.1 & 0.1 & 0.3 \\
\hline \multicolumn{13}{|c|}{ Agricultural land $\mathrm{P}$ budget per unit area $\left(\mathrm{kgPha}^{-1} \mathrm{yr}^{-1}\right)^{\mathrm{a}}$} \\
\hline Cropland & 4.7 & -1.0 & -1.5 & -2.7 & 23.4 & 4.1 & 0.2 & 5.2 & 2.8 & 1.5 & 3.8 & 2.3 \\
\hline Pasture & 0.4 & 0.2 & 1.6 & 0.9 & 1.0 & 0.4 & 0.6 & 0.8 & -0.4 & -0.1 & 3.4 & 0.4 \\
\hline \multicolumn{13}{|c|}{ Food consumption $\left(\mathrm{TgPyr}^{-1}\right)$} \\
\hline Crops & 5.3 & 0.2 & 0.3 & 0.2 & 1.4 & 1.3 & 0.3 & 0.0 & 0.8 & 0.4 & 0.0 & 0.3 \\
\hline Meat & 0.71 & 0.01 & 0.01 & 0.01 & 0.29 & 0.05 & 0.01 & 0.01 & 0.17 & 0.10 & 0.00 & 0.05 \\
\hline Eggs & 0.16 & 0.00 & 0.00 & 0.00 & 0.07 & 0.02 & 0.01 & 0.00 & 0.03 & 0.02 & 0.00 & 0.01 \\
\hline Milk & 0.60 & 0.01 & 0.03 & 0.00 & 0.04 & 0.13 & 0.04 & 0.01 & 0.18 & 0.09 & 0.01 & 0.05 \\
\hline \multicolumn{13}{|c|}{ PUE } \\
\hline Cropland & 0.46 & 0.80 & 0.84 & 1.51 & 0.27 & 0.43 & 0.64 & 0.31 & 0.54 & 0.57 & 0.53 & 0.63 \\
\hline Pasture & 0.72 & 0.77 & 0.61 & 0.46 & 0.58 & 0.80 & 0.61 & 0.42 & 1.25 & 0.98 & 0.37 & 0.75 \\
\hline Livestock & 0.06 & 0.02 & 0.02 & 0.01 & 0.08 & 0.05 & 0.04 & 0.04 & 0.09 & 0.08 & 0.03 & 0.03 \\
\hline Food & 0.45 & 0.60 & 0.50 & 0.64 & 0.40 & 0.64 & 0.44 & 0.26 & 0.28 & 0.32 & 0.68 & 0.42 \\
\hline \multicolumn{13}{|c|}{ International trade of $\mathrm{P}$ in commodities $\left(\mathrm{Tg} \mathrm{Pyr}^{-1}\right)^{\mathrm{b}}$} \\
\hline Crops & - & 0.02 & 0.12 & 0.03 & 0.35 & 0.03 & 0.12 & -0.07 & -0.02 & -0.41 & 0.03 & -0.24 \\
\hline Meat & - & 0.000 & 0.001 & 0.000 & 0.013 & 0.000 & 0.002 & -0.004 & -0.002 & -0.005 & 0.001 & -0.010 \\
\hline Eggs & - & 0.0001 & 0.0000 & 0.0000 & 0.0001 & -0.0004 & 0.0001 & 0.0000 & 0.0000 & -0.0002 & 0.0000 & -0.0001 \\
\hline Milk & - & 0.000 & 0.003 & 0.001 & 0.004 & 0.005 & 0.004 & -0.015 & -0.012 & 0.003 & 0.001 & -0.001 \\
\hline Fertilizer & - & 0.05 & -0.67 & 0.03 & 0.00 & 1.45 & -0.05 & 0.21 & -0.37 & -1.00 & 0.06 & 1.10 \\
\hline
\end{tabular}

${ }^{a}$ The positive values represent a soil $\mathrm{P}$ surplus, whereas negative values represent a soil $\mathrm{P}$ deficit. ${ }^{\mathrm{b}}$ The positive values represent net $\mathrm{P}$ importers, whereas negative values represent net $P$ exporters.

\subsubsection{Regional pasture budgets}

We found mainly net losses of $\mathrm{P}$ in pasture soils (Fig. 4b), most likely because of the net removal of $\mathrm{P}$ through animal grazing, followed by the export of manure $\mathrm{P}$ to enrich cropland soils. Pasture soil $\mathrm{P}$ loss rates per unit area in Europe averaged $0.4 \mathrm{~kg} \mathrm{Pha}^{-1} \mathrm{yr}^{-1}$ and reached high values in countries (Denmark, Luxembourg, Germany, and Belgium) with intensive livestock production systems (Chang et al., 2015) and large grass consumption by livestock, with loss rates $>10 \mathrm{~kg} \mathrm{Pha}^{-1} \mathrm{yr}^{-1}$. North American pastures had a smaller average loss rate of about $0.1 \mathrm{~kg} \mathrm{Pha}^{-1} \mathrm{yr}^{-1}$. The United States, India, and Russia had the largest cumulative $\mathrm{P}$ deficits at $2.1,1.5$, and $0.7 \mathrm{Tg} \mathrm{P}$, respectively, from 2002 to 2010. In contrast, pasture in the Caribbean and Central America had greater P inputs than P removals. Consequently, these regions had the largest soil $\mathrm{P}$ accumulation rates. Pasture in northern and eastern Africa also had net soil $\mathrm{P}$ accumulation. For instance, Mauritania, Tunisia, and Morocco had net soil $\mathrm{P}$ accumulation rates of $9.8,9.4$, and $5.5 \mathrm{~kg} \mathrm{Pha}^{-1} \mathrm{yr}^{-1}$, respectively. The reason for this excess is not clear, but one possibility is that these countries apply $\mathrm{P}$ fertilizer to some of their pasture.

\subsection{Phosphorus-use efficiencies in different regions}

Table 1 gives the values of PUE for cropland, pasture, livestock, and food (human use) in the world's different regions. Globally, 116 countries have cropland PUE values above the global mean value of 0.46 , mostly in Africa, and these countries account for $64 \%$ of the global cropland area. In addition, $16 \%$ of the countries had a PUE of around $0.6(0.55$ to $0.65)$. In particular, African countries had the highest overall cropland PUE $(\geq 0.80)$ because of their low P input. On the other hand, eastern Asia and Oceania have cropland PUE below the global average. Conversely, pasture had high PUE in Europe (1.25) and North America (0.98) but low values in Africa $(\leq 0.77)$ and particularly low values in the Caribbean and Central America (0.37). P removal from pasture exceeded $\mathrm{P}$ inputs in Europe, resulting in pasture PUE $>1$, largely because of $\mathrm{P}$ inputs from feed given to animals.

The livestock subsystem generally had a low PUE $(<0.1)$, with the highest values in Europe, North America, and eastern Asia (Table 1). Regarding human food PUE, our data indicate that only 25 to $40 \%$ of the $\mathrm{P}$ in food products in eastern Asia, Oceania, Europe, and North America is actually consumed by humans (Table 1). The resulting low PUE of 
human use in these regions results from both large $\mathrm{P}$ inputs and high food waste. Eastern and southern Africa, western and central Africa, southern and southeastern Asia, and the Caribbean and Central America had the highest PUE for human use, with more than $60 \%$ of $\mathrm{P}$ in food being consumed by humans. Globally, most of the $\mathrm{P}$ consumed by humans ( $78 \%$ ) originates from crops, and the fraction of $\mathrm{P}$ from livestock differs among regions; it ranges from $35 \%$ of the total human food P consumption in Oceania, Europe, and North America to $10 \%$ in less developed regions (Africa and the Caribbean and Central America) and to $4 \%$ in western and central Africa.

\subsection{P flows through international trade}

Approximately $2.1 \mathrm{Tg} \mathrm{Pyr}^{-1}$ entered into international trade in 2010, amounting to about $17 \%$ of the total harvested crop $\mathrm{P}$ (Fig. 5). The remainder (10.6 $\left.\mathrm{TgP} \mathrm{Pr}^{-1}\right)$ is consumed domestically. Differences in crop types as a result of their specific $\mathrm{P}$ content (Table S1) strongly determine the magnitude of the traded P fluxes. For example, $37 \%$ of the P in soybeans and $27 \%$ of the $\mathrm{P}$ in wheat produced each year were traded internationally in 2010. Also significant fractions of the P in maize, other cereals, and fruit were traded internationally, but almost all of the $\mathrm{P}$ in sugar crops and fibre were consumed or processed in the countries where they were grown.

Considering the P fluxes in phosphate fertilizers and food products, we examined how international trade influences regional $\mathrm{P}$ budgets and redistributes $\mathrm{P}$ between regions. We found that southern and southeastern Asia have the largest net $\mathrm{P}$ imports (Table 1), with imports of phosphate fertilizer amounting to $1.4 \mathrm{TgPyr}^{-1}$ and $\mathrm{P}$ exports as food products being much smaller, mainly to China and South Korea. South America is the second-largest exporter of $\mathrm{P}$ in food, but imports $56 \%$ of its $\mathrm{P}$ fertilizer. North America is a large exporter of $\mathrm{P}$ in both crop products and fertilizer, yet it also imports P-rich milk products. Most European countries imported nearly all their phosphate fertilizers, but Europe as a whole is a net exporter because of large exports (0.9 Tg Pyr ${ }^{-1}$ ) from Russia (Fig. 6). Western European countries were the main exporters of P-rich livestock products. Some northern African countries (especially Morocco and Tunisia, which have the largest mines of P-rich ores) exported a total of $0.7 \mathrm{Tg} \mathrm{Pyr}^{-1}$ in fertilizer. The remaining regions (eastern and southern Africa, northern Africa, and the Caribbean and Central America) imported P in both food and fertilizer, although much less than other regions (Table 1).

Figure 6 illustrates the disparities among countries with respect to the role of international trade in crops, livestock, and fertilizer for the main exporters and importers. Based on data for all 224 countries, a country can be categorized into one of the following four groups (Fig. 7).

Food and fertilizer $P$ exporters. $\mathrm{P}$ storage in these countries has been decreasing due to their international exports of
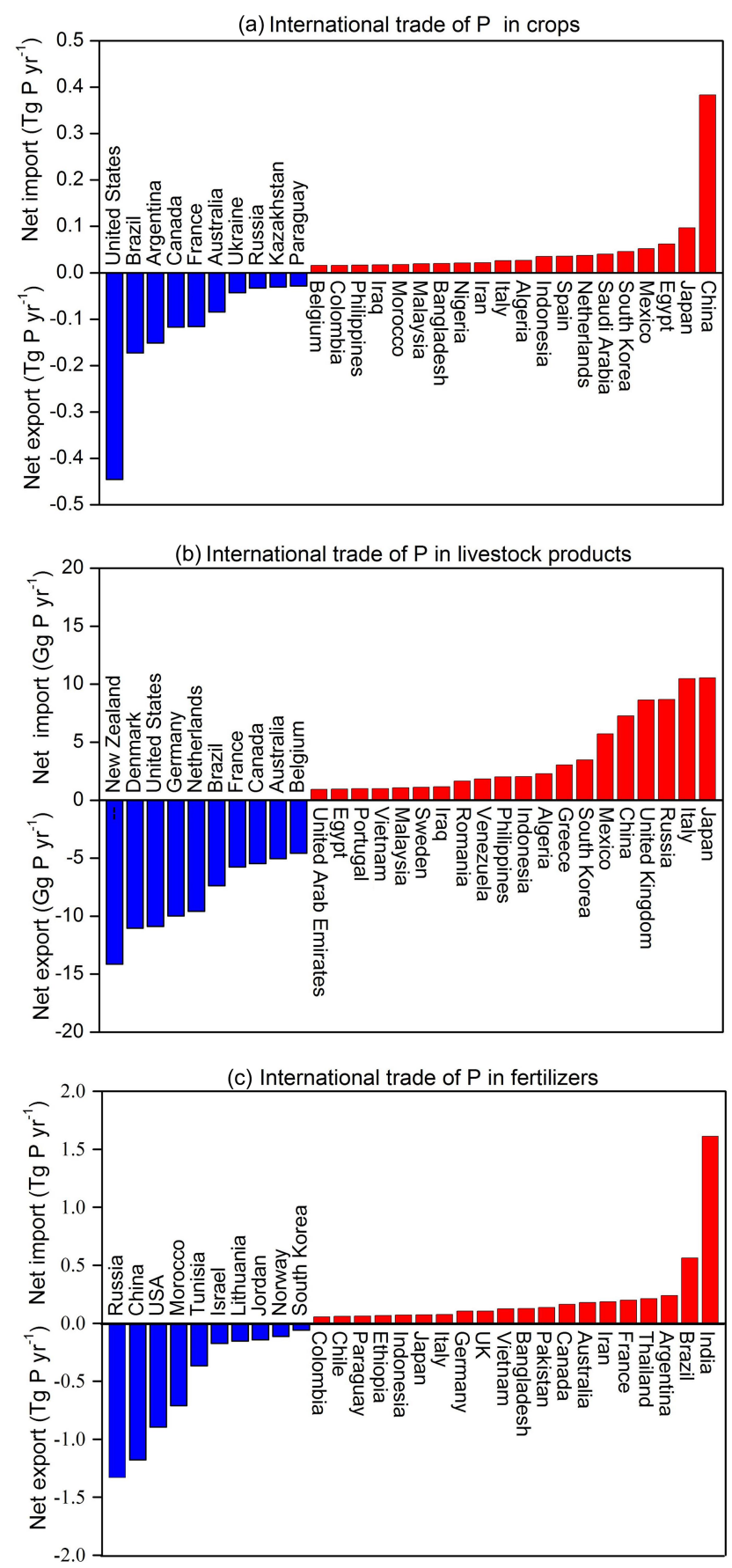

Figure 6. Annual P flows embedded in traded crop products (a), livestock products (b), and fertilizers (c) in 2010. By convention, a positive flow is $\mathrm{P}$ received (imported) by a country.

both fertilizer and food. Examples include the United States and Russia.

Food $P$ importers and fertilizer $P$ exporters. This group mainly comprises countries that export phosphate fertilizers and import food to meet domestic consumption. Examples includes Tunisia, Morocco, and China. 


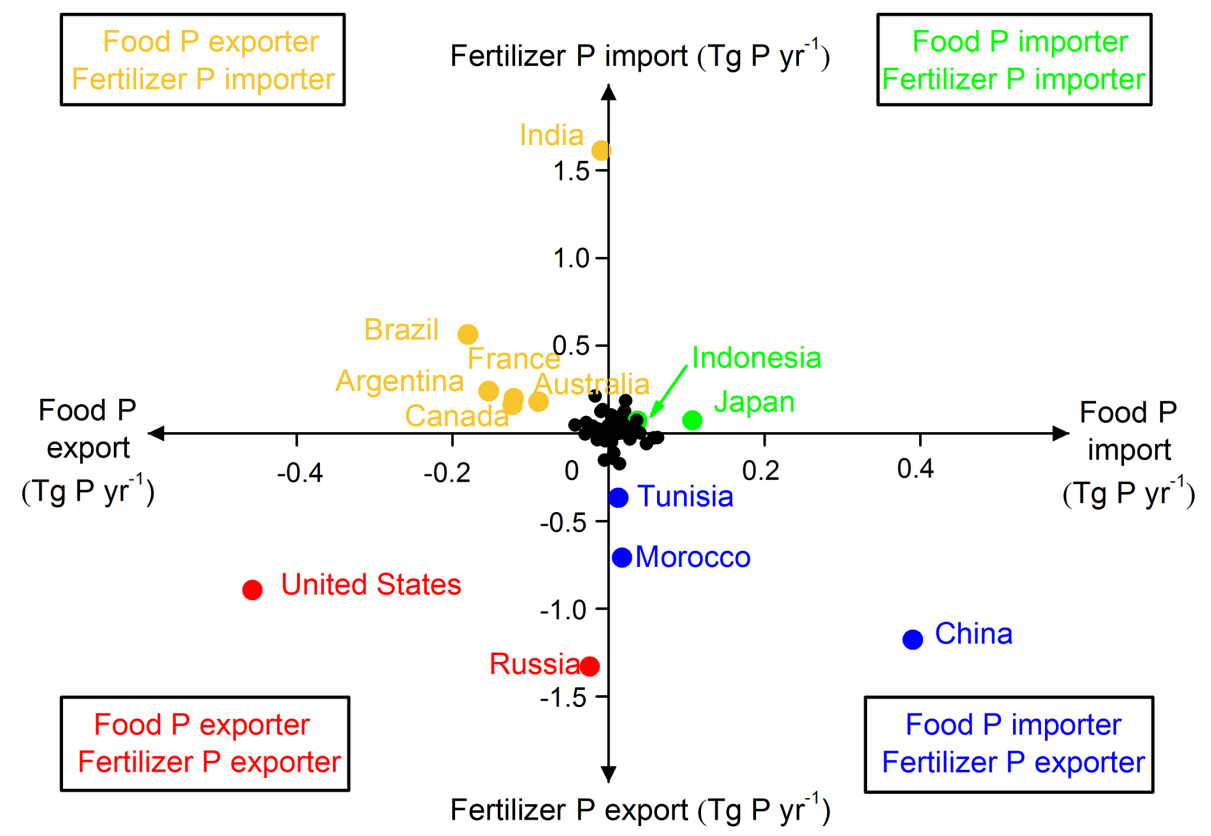

Figure 7. Groupings of the countries based on whether they import or export $\mathrm{P}$ through their international trade in food and fertilizer.

Food $P$ exporters and fertilizer $P$ importers. These countries have high food and livestock production, but this depends strongly on phosphate fertilizer imported from other countries. Examples include Brazil, Argentina, Canada, France, Australia, and India.

Food and fertilizer P importers. These countries depend on imports for both food and fertilizers; they are thus vulnerable to economic shocks that result from changing food prices. Examples include Japan and Indonesia.

International trade affects the global P cycle by physically moving the $\mathrm{P}$ contained in traded crops, livestock products, and phosphate fertilizers (Grote et al., 2005). Imports of $P$ fertilizers accounted for 55 and $79 \%$, respectively, of the total application of $\mathrm{P}$ fertilizer for countries that are food $\mathrm{P}$ exporters and fertilizer $\mathrm{P}$ importers or food and fertilizer $\mathrm{P}$ importers. The $\mathrm{P}$ trade in food followed a similar trend. Countries that are food $\mathrm{P}$ importers and fertilizer $\mathrm{P}$ exporters or food and fertilizer P importers depended more on food imports than countries that are food and fertilizer $\mathrm{P}$ exporters or food P exporters and fertilizer P importers. International trade also increased the connections among countries (Table 2). For example, although the United States and China are clearly major $\mathrm{P}$ fertilizer exporters, they also import fertilizer from each other; $2.6 \%$ of the $\mathrm{P}$ fertilizer applied in the United States originated in China, and $3.6 \%$ of the phosphate fertilizer applied in China originated in the United States. In addition, $11.4 \%$ of the phosphate fertilizer consumption in the United States originated from Russia, Morocco, Tunisia, and other countries. About $1.5 \%$ of Chinese domestic P consumption originates from the United States, which is higher than the fraction of domestic P consumption in the United
States from China. Countries with small or no reserves of P-containing minerals imported large amounts of phosphate fertilizer; for example, imports accounted for 61 and $46 \%$ of total $\mathrm{P}$ consumed in France and Brazil (food $\mathrm{P}$ exporters and fertilizer P importers) and $76 \%$ of total P consumed in Japan.

\subsection{Uncertainties in soil $\mathrm{P}$ changes result from uncertain $\mathrm{P}$ concentrations}

We estimated the net cropland soil P balance in 2000 by means of Monte Carlo simulations, as described in Sect. 2.7. We found a net accumulation of $5.8 \pm 0.6 \mathrm{Tg} \mathrm{Pyr}^{-1}$. More detailed calculations suggest that uncertainty in the crop $\mathrm{P}$ concentrations contributed $\pm 0.2 \mathrm{Tg} \mathrm{Pyr}^{-1}$ of the uncertainty in the net cropland soil $\mathrm{P}$ balance; this is because of the dominance of calculations using cereals, which have low uncertainty due to the narrow range of reported $\mathrm{P}$ concentrations (Antikainen et al., 2005; COMIFER, 2007; USDA-NRCS, 2009; Waller, 2010). Uncertainty in $P$ concentrations in crop residues contributed an additional $\pm 0.2 \mathrm{TgP}^{-1}$ to the total uncertainty, and uncertainty in $\mathrm{P}$ concentrations in the livestock manure applied to cropland added $\pm 0.4 \mathrm{Tg} \mathrm{Pyr}^{-1}$. In addition, the uncertainty in the pasture soil $\mathrm{P}$ balance attributed to uncertainty in the $\mathrm{P}$ concentrations in grass biomass and manure was $\pm 1.3 \mathrm{TgPyr}^{-1}$. This relative uncertainty is higher than that for the cropland soil $\mathrm{P}$ balance and the results from the large range of grass $\mathrm{P}$ concentrations found in our review of the available data. See Table S5 for more details. 
Table 2. Proportions of total consumption and total international trade accounted for by $\mathrm{P}$ in fertilizer and food imports and exports.

\begin{tabular}{|c|c|c|c|c|}
\hline \multirow[b]{2}{*}{ Group } & \multicolumn{4}{|c|}{ Proportion $(\%)$} \\
\hline & $\begin{array}{c}\text { P fertilizer } \\
\text { imports as a } \\
\text { proportion of total } \\
\text { consumption }\end{array}$ & $\begin{array}{l}\text { P fertilizer exports } \\
\text { as a proportion } \\
\text { of the total } \\
\text { international } \mathrm{P} \\
\text { fertilizer trade }\end{array}$ & $\begin{array}{l}\mathrm{P} \text { in food imports } \\
\text { as a proportion of } \\
\text { total consumption }\end{array}$ & $\begin{array}{l}\mathrm{P} \text { in food exports as } \\
\text { a proportion of the } \\
\text { total international } \\
\mathrm{P} \text { in the food trade }\end{array}$ \\
\hline \multicolumn{5}{|c|}{ Group level } \\
\hline Food and fertilizer exporter & 22 & 43 & 7 & 31 \\
\hline Food importer and fertilizer exporter & 5 & 48 & 22 & 5 \\
\hline Food exporter and fertilizer importer & 55 & 5 & 5 & 48 \\
\hline Food and fertilizer importer & 79 & 4 & 28 & 15 \\
\hline \multicolumn{5}{|c|}{ Country level } \\
\hline United States (food and fertilizer exporter) & 13 & 18 & 6 & 26 \\
\hline China (food importer and fertilizer exporter) & 2 & 20 & 14 & 2 \\
\hline France (food exporter and fertilizer importer) & 52 & 0 & 19 & 8 \\
\hline Brazil (food exporter and fertilizer importer) & 44 & 1 & 4 & 10 \\
\hline Japan (food and fertilizer importer) & 40 & 0 & 60 & 0 \\
\hline
\end{tabular}
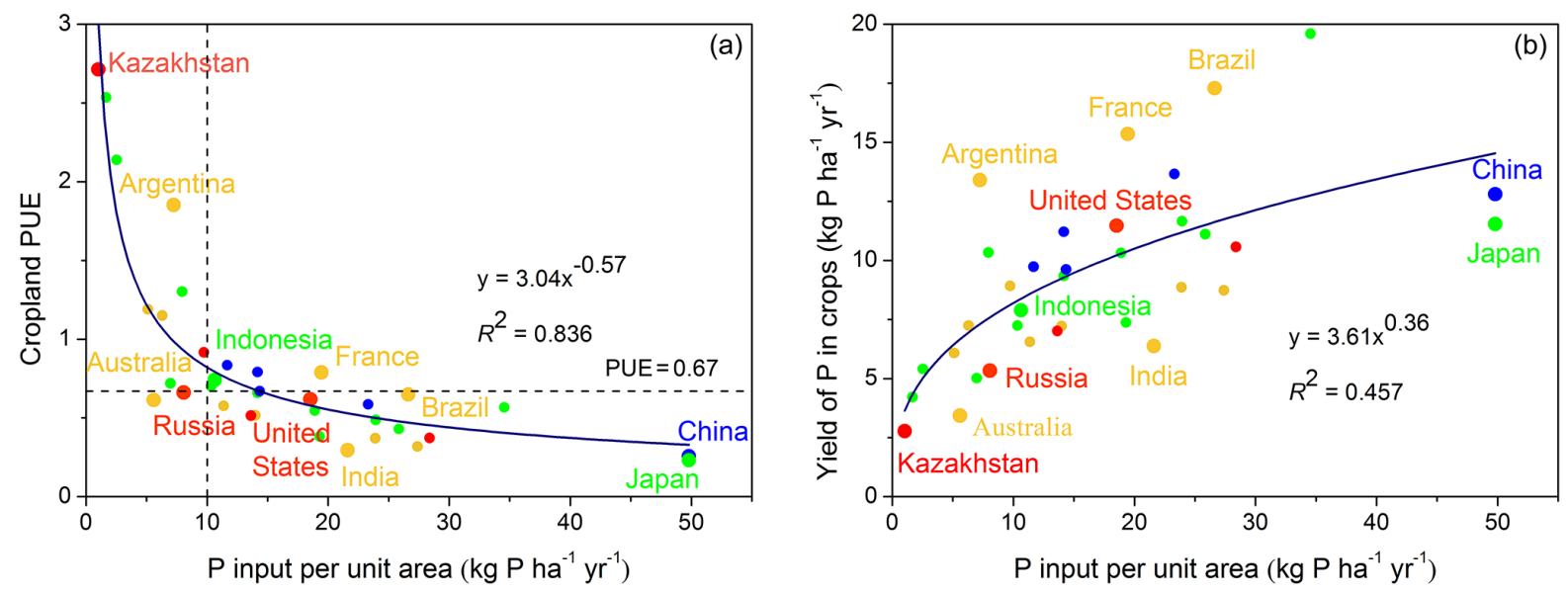

Figure 8. The relationships between $\mathrm{P}$ input per unit area of cropland and (a) phosphorus-use efficiency (PUE) The horizontal line at $\mathrm{PUE}=0.67$ represents the global average. (b) $\mathrm{P}$ in harvested crops for the 35 largest crop producers representing $90 \%$ of global crops. The equations give the fit to the data represented by black curves.

\section{Discussion}

\subsection{Cropland PUE and $P$ in harvested crops as a function of cropland $P$ inputs}

Figure 8a shows the relationship between the cropland PUE and cropland $\mathrm{P}$ inputs for 35 countries that are large crop producers. PUE decreased exponentially with increasing input; that is, $\mathrm{P}$ was used most efficiently at low application rates. PUE decreased rapidly as $\mathrm{P}$ inputs increased to $10 \mathrm{~kg} \mathrm{Pha}^{-1} \mathrm{yr}^{-1}$ and then decreased more slowly. High PUE values were associated with countries that had a low $\mathrm{P}$ input and a soil P deficit. This suggests that there is a trade-off between the efficient use of $\mathrm{P}$ in cropland and the avoidance of soil P deficits that limit crop yields (Obersteiner et al., 2013). Figure $8 \mathrm{a}$ also indicates that cropland soils have a net soil $\mathrm{P}$ deficit if their inputs are lower than $10 \mathrm{~kg} \mathrm{Pha}^{-1} \mathrm{yr}^{-1}$, which is a threshold value that corresponds to PUE $=0.67$. Argentina, South Africa, Indonesia, Mexico, and Paraguay are below this threshold (Fig. 9).

$\mathrm{P}$ in harvested crops increased exponentially with increasing $\mathrm{P}$ inputs, but the response slowed at high $\mathrm{P}$ inputs (Fig. 8b). The $\mathrm{P}$ in harvested crops in countries with cropland PUE $>0.67$ (except Argentina) is only half of that in countries with high $\mathrm{P}$ in the harvested crops, such as the United States and China. P in the harvested crops was very low in Australia due to low cropland P input, which was less 


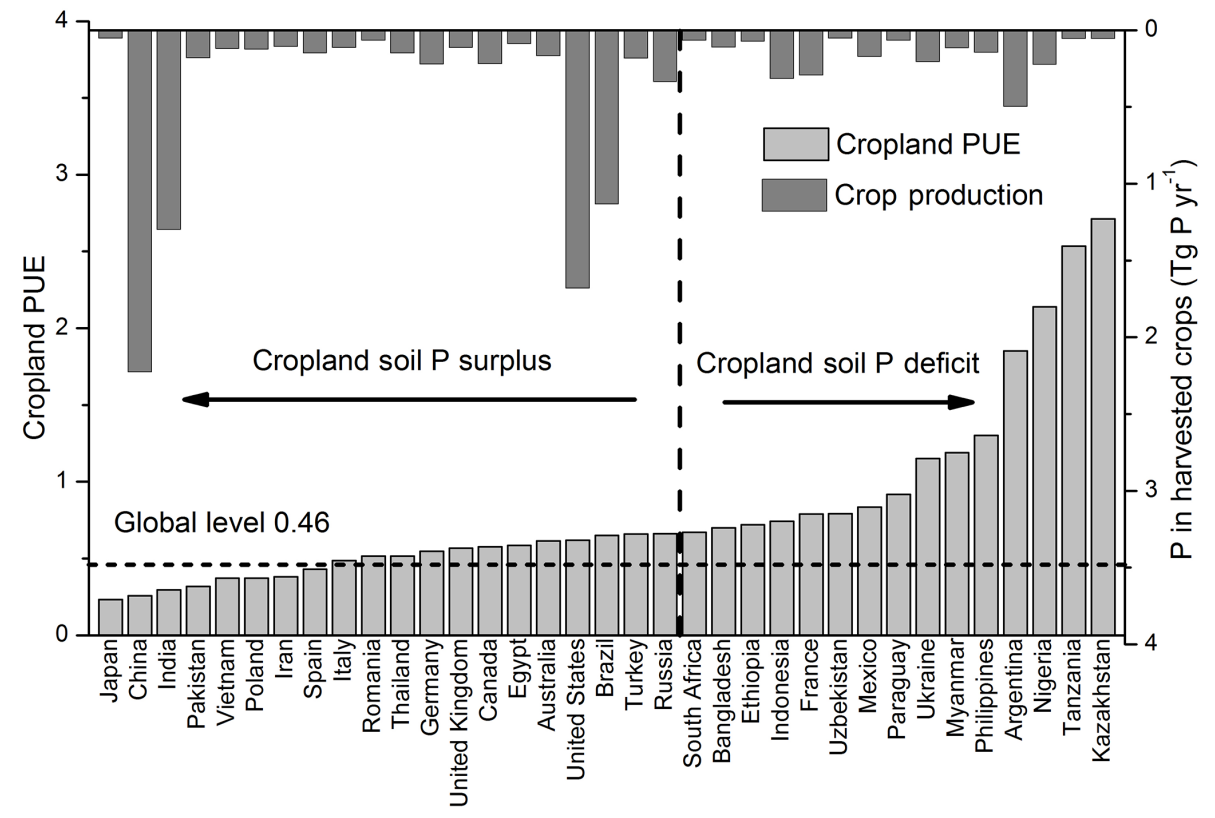

Figure 9. Phosphorus-use efficiency (PUE) and P in harvested crops for the 35 large countries shown in Fig. 8. Cropland soil P surplus or deficit is separated by the vertical dashed line.

than $25 \%$ of the inputs in the United States and China. P already present in the soil may be sufficient to sustain high crop yields for some time without additional inputs in some countries (e.g. France) that formerly had large $\mathrm{P}$ fertilization rates, despite currently having a negative annual $\mathrm{P}$ balance. Comparing Fig. 8a and $\mathrm{b}$ suggests that total cropland $\mathrm{P}$ inputs of 20 to $25 \mathrm{~kg} \mathrm{Pha}^{-1} \mathrm{yr}^{-1}$ may be a good compromise that will achieve high yields while creating a near-equilibrium soil $\mathrm{P}$ balance. Both excessive P inputs (e.g. China and Japan) and low PUE (e.g. India) can lead to high P accumulation in cropland soil, leading to high losses into the environment.

The data in Fig. 8 indicate that different countries face different challenges for $\mathrm{P}$ resource management, implying a need for country-specific policy options and solutions. Countries like Kazakhstan and Argentina may have to increase $\mathrm{P}$ inputs to their cropland in order to prevent long-term depletion of soil $\mathrm{P}$, which could be realized by increasing the application of phosphate fertilizer or reducing losses to leaching and erosion. Countries like France that are currently experiencing a net negative soil P balance (Fig. 9) following a period of sustained accumulation (Senthilkumar et al., 2012; van Dijk et al., 2016) may need to progressively adjust fertilizer inputs in coming years to balance inputs with removals and avoid the risk of a long-term soil fertility decline due to inadequate levels of P. In contrast, countries such as Japan and China are rapidly accumulating $\mathrm{P}$ in cropland soils due to high and sustained $\mathrm{P}$ inputs and will urgently need to consider how to improve their cropland PUE. This could be initiated by identifying crop types that are being over-fertilized and regions with excessive application of phosphate fertilizer; they can then consider a range of options such as precision agriculture (i.e. applying only as much $\mathrm{P}$ as the crop requires). We estimate that if Chinese cropland PUE could be increased to the global average of 0.46 (Fig. 9), China would save $3.8 \mathrm{Tg} \mathrm{Pyr}^{-1}$ of phosphate fertilizer, which is equivalent to $60 \%$ of its phosphate fertilizer consumption in 2010. Last, in countries like India where crop P harvests are lower than average despite high average $\mathrm{P}$ inputs and positive soil $\Delta P$, improvements in agricultural management (such as the use of precision fertilization) appear necessary. We did not have access to subnational data for this study, but it is likely that in a country as large as India, excessive or insufficient $\mathrm{P}$ may occur in different regions, for different crop types, or for different region-crop-type combinations.

\subsection{Pasture P budget, livestock consumption, and international trade}

Figure 10 shows that the soil $\mathrm{P}$ balance is negatively related to the flux of $\mathrm{P}$ in livestock products per unit area of pasture. Several western European countries (Germany, the Netherlands, Denmark, and Belgium) achieve high P yields in livestock products (defined by the amount of $\mathrm{P}$ in livestock products per unit area of pasture), and all of these countries export livestock products. In these countries, only a small fraction of livestock manure is recycled to pasture, so there is currently a soil $\mathrm{P}$ deficit; in the long term, this may result in a loss of soil fertility. Therefore, these countries should increase $P$ fertilization in pasture or import forage or feed to supply the $\mathrm{P}$ required to sustain high livestock production. New Zealand, Australia, and Canada are also large exporters of $\mathrm{P}$ in live- 


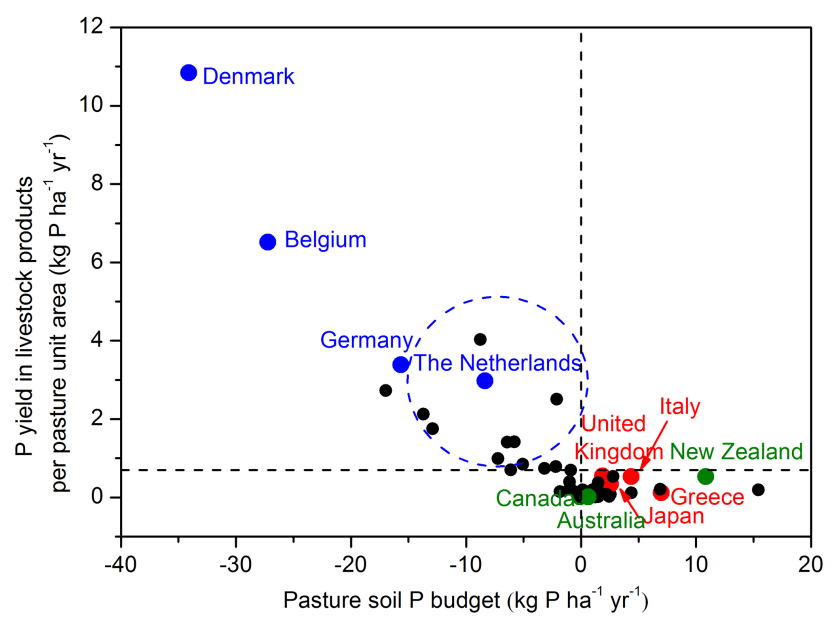

Figure 10. The relationship between the $\mathrm{P}$ yield of livestock products, defined by the amount of $\mathrm{P}$ in livestock products per unit area of pasture and the $\mathrm{P}$ balance of pasture soils.

stock products. However, given their low-input production systems and large areas of pasture (Fig. 4b), P removals per unit area through grazing are much lower than in western Europe, and the soil $\mathrm{P}$ balance of pasture ranges from slightly negative to slightly positive.

\subsection{Livestock and human food PUE and trends in P consumption}

The increasing consumption of livestock products by humans is an essential factor that is responsible for increasing $\mathrm{P}$ mining and increasing $\mathrm{P}$ inputs to agricultural systems (Metson et al., 2012; van Dijk et al., 2016). Where socioeconomic development is improving the income of residents, especially in Africa and the Caribbean and Central American region, residents are consuming more $\mathrm{P}$ from livestock products (Fig. S3). Unfortunately, the livestock PUE in countries in these two regions is much smaller $(0.01$ to 0.03$)$ than the global average of 0.06 (Table 1), indicating that only a small proportion of livestock $\mathrm{P}$ inputs is used by humans. This may be because countries in these regions are primarily importers of livestock products. Therefore, animal husbandry has important implications for global P security and special attention will be required to improve livestock PUE (Wu et al., 2014). If livestock PUE reaches the global level of 0.06 in these two regions, both regions could more than double their livestock production by about $0.16 \mathrm{Tg} \mathrm{Pyr}^{-1}$.

In addition, the management of manure differs greatly among regions due to different livestock production systems. The yield of livestock products is very low in African countries, resulting in low livestock PUE. Almost all livestock manure is applied to cropland for which this resource is an important $\mathrm{P}$ input. In contrast, with the application of phosphate fertilizer to pasture in Europe and eastern Asia, only a small fraction of livestock manure is recycled for pasture
(36 and $17 \%$, respectively); a larger fraction of the manure is applied to cropland in eastern Asia (40\%) and Europe $(60 \%)$. Consequently, improving the manure utilization efficiency and applying more livestock manure to pasture will be important strategies in eastern Asia and Europe (Wu et al., 2014).

As shown in Sect. 3.3, only $45 \%$ of the P that enters the food production subsystem was absorbed by humans; thus, large amounts of food (and the P it contains) are wasted, although some parts of the waste were consumed by livestock. Despite this recycling, $2.2 \mathrm{Tg} \mathrm{Pyr}^{-1}$ flowed into the environment as waste either before or after food consumption, and only $14.3 \%$ of the total $\mathrm{P}$ inputs to the agriculture system ended up in food consumed by humans. In eastern Asia, Oceania, Europe, and North America, the PUE of human food was very low, reflecting the high proportion of livestock products in the diet and a high degree of waste. Therefore, decreasing food waste before consumption, recycling $\mathrm{P}$ in food waste, and better treatment of organic waste could significantly decrease the amount of $\mathrm{P}$ required to support humans (Metson et al., 2012; van Dijk et al., 2016). In eastern Asia, Oceania, Europe, and North America, fully absorbing the $45 \%$ of the $\mathrm{P}$ that enters food produced for humans could reduce agricultural inputs of $\mathrm{P}$ by $0.7 \mathrm{Tg} \mathrm{Pyr}^{-1}$ globally. Thus, decreasing food waste and improving the PUE of human food represent key challenges that must be solved to achieve sustainable $\mathrm{P}$ management.

Population increases and dietary changes are requiring higher $\mathrm{P}$ inputs in cultivated land and the increased mining of P ores (Grote et al., 2005; Foley et al., 2011). From 2002 to 2010 , this mining increased by $33 \%$ in our estimate, during a period when the global population and per capita food $\mathrm{P}$ consumption increased by 10 and $5 \%$, respectively. In 2010, humans consumed 8.0 and $3.8 \%$ more $\mathrm{P}$ in livestock products and crops, respectively. Since livestock PUE was much lower than cropland PUE, the consumption of more livestock products resulted in lower external $\mathrm{P}$ inputs in food that flowed into the human subsystem; this proportion decreased from $36 \%$ in 2002 to $31 \%$ in 2010 . Therefore, consuming more livestock products will require increasing $\mathrm{P}$ inputs. Thus, human dietary shifts may have been responsible for half of the increase of P-ore mining.

\subsection{International trade and global P flows}

International trade also increased the connections among countries. Whether international trade is good or bad for humans and the environment in terms of its impact on the management of $\mathrm{P}$ resources is a complex question. International trade can increase cropland $\mathrm{P}$ deficits if countries that export large amounts of $\mathrm{P}$ in crop and livestock products do not counteract these exports by increasing inputs of phosphate fertilizer to soils. For example, Argentina exported lots of food to other countries (about $0.15 \mathrm{TgPyr}^{-1}$ ) and has developed a serious cropland soil $\mathrm{P}$ deficit of $0.38 \mathrm{TgPyr}^{-1}$ 
(10.3 $\left.\mathrm{kgPha}^{-1} \mathrm{yr}^{-1}\right)$. Massive $\mathrm{P}$ imports through trade can result in an excess supply of $\mathrm{P}$ to cropland soils as manure (Schipanski and Bennett, 2012), with potentially significant negative environmental effects. On the one hand, trade can hamper the proper recycling of $\mathrm{P}$ resources from waste and manure to agricultural soils through local food webs (Schipanski and Bennett, 2012). On the other hand, trade may contribute to more efficient use of $\mathrm{P}$ resources if traded products flow from countries with lower PUE to countries with higher PUE, as is generally observed for water resources (Dalin et al., 2014). This confirms that more integrated studies are required to fully assess the effects of trade on $\mathrm{P}$ resource recycling, efficiency, and conservation. Our study identified world regions and countries with lower PUE and others with high PUE and regions and countries with a net loss of $\mathrm{P}$ in soils and others with a net gain. This provides valuable information to policymakers on how to improve the trade relationships for a global optimization of PUE and therefore global food security.

\subsection{Comparison with previous studies}

Previous studies have estimated $\mathrm{P}$ flows in agriculture on a global scale (Smil, 2000; Sheldrick et al., 2003; Liu et al., 2008; Cordell et al., 2009; Bouwman et al., 2009, 2013; Potter et al., 2010; MacDonald et al., 2011). However, to the best of our knowledge, the present analysis provides the first consistent multi-year overview of the $\mathrm{P}$ flows in agriculture. In addition, it provides national and regional $\mathrm{P}$ budgets, calculates agricultural PUE, and quantifies $\mathrm{P}$ fluxes in international trade based on a combination of datasets for cropland and pasture inputs (fertilizers, manure, atmospheric deposition, and recycling of crop residues) and outputs (crop harvests, residue removal, and $\mathrm{P}$ loss by burning and leaching or surface run-off into bodies of water). For data from 2000, our results are consistent with the abovementioned studies for most $\mathrm{P}$ flows (Table 3). For data from 2000, our results are generally consistent with those in the previous studies for cropland soil P inputs, harvested crop P, cropland soil P lost by erosion or surface run-off into bodies of water, pasture soil $\mathrm{P}$ inputs, and harvested grass $\mathrm{P}$ (Table 3 ). However, methods, data sources, and system boundaries differed among the studies, making an accurate comparison difficult. Our estimate of a net accumulation of $5.8 \pm 0.6 \mathrm{Tg} \mathrm{Pyr}^{-1}$ is in line with the reported net accumulation in soils, which ranged between 0 and 11.5 $\mathrm{TgPyr}^{-1}$ (Smil, 2000; Bennett et al., 2001; Bouwman et al., 2009; MacDonald et al., 2011), but disagrees with the estimate of Liu et al. (2008), who calculated a net loss of 9.6 $\mathrm{TgP}_{\mathrm{Pr}}{ }^{-1}$. The difference from the present results can be explained by accounting for large $\mathrm{P}$ losses (19.3 $\mathrm{TgP}_{\mathrm{Pr}}{ }^{-1}$ ) due to soil erosion caused by land-use change and overgrazing. The quantification of erosional losses of $\mathrm{P}$ from arable land is prone to high uncertainties due to the unknown amount of redeposited soil material, and other studies have reported much lower losses (e.g. 2.5 $\mathrm{Tg} \mathrm{Pyr}^{-1}$; Quinton et al., 2010)

The main cropland $\mathrm{P}$ fluxes estimated in our study agreed with previous results, except for the production and recycling of crop residues (Table 3). Smil (2000) and Liu et al. (2008) used harvest index data (defined as the ratio of total aboveground biomass to crop residues) for estimating the $\mathrm{P}$ in crop residues, whereas we estimated $\mathrm{P}$ in crop residues by combining data from Liu et al. (2008) and FAO. MacDonald et al. (2011) estimated that $29 \%$ of the global cropland area was subject to soil P deficits in 2000, which is similar to our estimate (32\%) based on data from 2002 to 2010. In addition, our estimate of $22.3 \mathrm{Tg} \mathrm{Pyr}^{-1}$ in animal manure for the livestock subsystem in 2000 is within the reported range of 17.1 to $24.3 \mathrm{Tg} \mathrm{Pyr}^{-1}$ from Potter et al. (2010). We defined global cropland PUE as the ratio of $\mathrm{P}$ in harvested crops to total $\mathrm{P}$ inputs without accounting for the recycling of crop residues. Under this definition, global PUE was estimated to be 0.43 by Liu et al. (2008) and 0.40 by Smil (2000), both of which are comparable to our estimate of 0.46 from 2002 to 2010. Since we applied the same methods across the globe to calculate agricultural $\mathrm{P}$ fluxes, we were able to compare the $\mathrm{P}$ fluxes and budgets for different regions and countries on a consistent basis. This information is of critical importance for the development of more appropriate agricultural policy and to support the development of technological and other solutions for different types of countries, which better integrate cultivated ecosystems, livestock production, and the human food supply.

\subsection{Limitations and novelty of our study}

Due to limited data sources for some parameters, our study and most previous studies focused on $\mathrm{P}$ in livestock products and manure as the outputs of the livestock system and did not consider the fate of $\mathrm{P}$ in non-edible livestock products (e.g. bones, blood, leather products). Xu et al. (2005) pointed out that from 12 to 23 and $72 \%$ of $P$ were contained in livestock meat and bones, respectively. If these percentages are applied to our data, this gives an annual flux of $2.5 \mathrm{TgPyr}^{-1}$ in the bones of slaughtered animals. Although most livestock bones are currently wasted or landfilled, some countries have begun to use them as fertilizers, protein sources, and condiments (Wu and Ma, 2005; Li, 2008). In addition, as we focused on the annual P budgets for livestock and human beings, we did not account for $\mathrm{P}$ accumulation in humans. From 2002 to 2010 , the global population increased by $635 \times 10^{6}$ persons. If we assume that a typical adult body contains $600 \mathrm{~g}$ of $\mathrm{P}$, then about $0.38 \mathrm{Tg}$ more $\mathrm{P}$ would have accumulated in humans. Therefore, the annual human $\mathrm{P}$ accumulation would be $0.04 \mathrm{TgPyr}^{-1}$, accounting for only $0.3 \%$ of the $\mathrm{P}$ inputs into humans.

Despite the abovementioned limitations in our study, we were able to achieve some interesting and novel results. First, we have provided a detailed and harmonized summary of 
Table 3. Comparison of the present results for $\mathrm{P}$ flows and budgets in 2000 with the results of other studies at a global level ( $\mathrm{Tg} \mathrm{Pyr}^{-1}$ ).

\begin{tabular}{llrrl}
\hline Global P flux & Previous studies & Our study & Reasons for differences \\
\hline \multirow{2}{*}{ Cropland } & Fertilizer input & $14-15^{1-3}$ & 13.7 & - \\
& Animal manure to cropland & $6-8^{2,3}$ & $6.7 \pm 0.4$ & Method \\
& Human sewage sludge to cropland & $1.5^{1,3}$ & 1.3 & Method \\
& Crop production & $-2-12.3^{1-5}$ & $10.2 \pm 0.4$ & Boundary/data \\
& Crops (human food) & $3.5^{3}$ & $4.8 \pm 0.2$ & Method/data \\
& Crops (animal feed) & $2.6^{3}$ & $1.9 \pm 0.1$ & Data \\
& Crop residues & $3.75-4.5^{1-2}$ & $6.7 \pm 0.2$ & Method/data \\
& Recycling of residues & $1-2.2^{1-3}$ & $3.5 \pm 0.1$ & Method/data \\
& Leaching and run-off from cropland & $4^{6}$ & 3.2 & Method \\
\hline \multirow{2}{*}{ Pasture } & Livestock manure & $17.1-24.3^{5,7,8}$ & $22.3 \pm 1.3$ & Method/data \\
& Manure wasted (released into the environment) & $2-8^{1-3}$ & $4.1 \pm 0.2$ & Method/data \\
& Grass & $6-12.1^{3,4}$ & $8.9 \pm 1.3$ & Method/data \\
& Animal feed additives & $0.9^{3}$ & 1.4 & Data \\
& Leaching and run-off from pasture & $1.0^{5}$ & 1.6 & Method \\
\hline \multirow{2}{*}{ Humans } & Excreta & $3-3.3^{1,3}$ & 2.8 & Method \\
\hline
\end{tabular}

Sources: ${ }^{1}$ Liu et al. (2008), ${ }^{2}$ Smil (2000), ${ }^{3}$ Cordell et al. (2009), ${ }^{4}$ MacDonald et al. (2011), ${ }^{5}$ Bouwman et al. (2009), ${ }^{6}$ Bouwman et al. (2013), ${ }^{7}$ Sheldrick et al. (2003), ${ }^{8}$ Potter et al. (2010).

the $\mathrm{P}$ fluxes as inputs and outputs for the agricultural system and the internal $\mathrm{P}$ flows within the agricultural system on national, regional, and global scales. In addition, we have characterized the $\mathrm{P}$ budgets and $\mathrm{P}$-use efficiencies in the subsystems of the overall agricultural system and discussed their influences and impacts. Finally, we have discussed how changes in population, diets, and food consumption have influenced the global mining of $\mathrm{P}$ ore and how international trade has influenced $P$ fluxes. These insights will support the development of policies to use $\mathrm{P}$ more sustainably at national, regional, and global levels.

\section{Data availability}

The global and regional phosphorus budgets and their PUEs in agricultural systems are publicly available at https://doi. pangaea.de/10.1594/PANGAEA.875296.

\section{Conclusions}

The estimation of global and regional phosphorus budgets in agricultural systems and their PUE is a major effort by the anthropogenic nutrient cycle research community that requires lots of work. We quantified in detail the $\mathrm{P}$ inputs and outputs of cropland and pasture and the $\mathrm{P}$ fluxes through human and livestock consumers of agricultural products on global, regional, and national scales from 2002 to 2010. The results from this analysis confirmed that $\mathrm{P}$ from phosphate fertilizers is the largest single input flux into the agricultural system, while one-half of this input was lost to freshwaters and one-third accumulated in soils. Chemical fertilizer in- puts, $\mathrm{P}$ losses to the environment, and $\mathrm{P}$ harvested in crop biomass all present increasing trends. The positive global $\mathrm{P}$ balance in cropland and pasture soils is the sum of regional excess and deficits, with differences in the sign of the balance between cropland and pastures as well. Compared with croplands, a slightly larger proportion of the global pasture area had a net annual soil P deficit. The hot spots of cropland $\mathrm{P}$ budgets are on the one hand eastern Asian countries with excessive inputs and sub-Saharan African countries with deficits. Hot spots of pasture P budgets are European and North American grazing lands showing significant soil P deficits. There are great differences in PUE for croplands, pastures, livestock products, and food products on global, regional, and national scales. Livestock products generally had the lowest PUE. We showed that cropland PUE decreased exponentially with increasing input implying that $\mathrm{P}$ is used more efficiently at low application rates. In parallel, $\mathrm{P}$ in harvested crop biomass increased with $\mathrm{P}$ inputs following a saturating exponential relationship. International trade plays a significant role in the $\mathrm{P}$ redistribution among countries when considering $\mathrm{P}$ embedded in imported livestock and food products consumed in each country and the trade of fertilizers. Nearly one-fifth of total harvested crop P entered into international trade during the period 2002-2010. Population increases and dietary changes are requiring higher $\mathrm{P}$ inputs in cultivated land and the increased production of $P$ fertilizers from minerals. Human dietary shifts may have been responsible for half of the increase in $\mathrm{P}$ mining during the period 2002-2010. Regional P imbalances in agricultural soils can be mitigated both by optimizing phosphate fertilizer application and recycling $\mathrm{P}$. 


\section{The Supplement related to this article is available online at https://doi.org/10.5194/essd-10-1-2018-supplement.}

Competing interests. The authors declare that they have no conflict of interest.

Acknowledgements. This study was supported by the National Natural Science Foundation of China (41625001, 41571022), the Beijing Natural Science Foundation (grant 8151002), the Southern University of Science and Technology (grant no. G01296001), and a Synergy Grant (ERC-2013-SyG-610028 IMBALANCE-P) from the European Research Council.

Edited by: Attila Demény

Reviewed by: two anonymous referees

\section{References}

Antikainen, R., Lemola, R., Nousiainen, J. I., Sokka, L., Esala, M., Huhtanen, P., and Rekolainen, S.: Stocks and flows of nitrogen and phosphorus in the Finnish food production and consumption system, Agr. Ecosyst. Environ., 107, 287-305, 2005.

ASAE: Manure Production and Characteristics. D384.2, American Society of Agricultural Engineers, St. Joseph, MI, USA, 2005.

Bennett, E. M., Carpenter, S. R., and Caraco, N. F.: Human impact on erodable phosphorus and eutrophication: a global perspective: increasing accumulation of phosphorus in soil threatens rivers, lakes, and coastal oceans with eutrophication, BioScience, 51, 227-234, 2001.

Bouwman, A. F., Beusen, A. H., and Billen, G.: Human alteration of the global nitrogen and phosphorus soil balances for the period 1970-2050, Global Biogeochem. Cy., 23, https://doi.org/10.1029/2009GB003576, 2009.

Bouwman, L., Goldewijk, K. K., Van Der Hoek, K. W., Beusen, A. H., Van Vuuren, D. P., Willems, J., Rufino, M. C., and Stehfest, E.: Exploring global changes in nitrogen and phosphorus cycles in agriculture induced by livestock production over the 1900-2050 period, P. Natl. Acad. Sci. USA, 110, 20882-20887, 2013.

Carpenter, S. R. and Bennett, E. M.: Reconsideration of the planetary boundary for phosphorus, Environ. Res. Lett., 6, 014009, https://doi.org/10.1088/1748-9326/6/1/014009, 2011.

Carpenter, S. R., Caraco, N. F., Correll, D. L., Howarth, R. W., Sharpley, A. N., and Smith, V. H.: Nonpoint pollution of surface waters with phosphorus and nitrogen, Ecol. Appl., 8, 559-568, 1998.

Chang, J., Viovy, N., Vuichard, N., Ciais, P., Campioli, M., Klumpp, K., Matin, R., Leip, A., and Soussana, J. F.: Modeled changes in potential grassland productivity and in ruminant livestock density in Europe over 1961-2010, PLOS ONE, 10, e0127554, https://doi.org/10.1371/journal.pone.0127554, 2015.

Chang, J. F., Viovy, N., Vuichard, N., Ciais, P., Wang, T., Cozic, A., Lardy, R., Graux, A.-I., Klumpp, K., Martin, R., and Soussana, J.-F.: Incorporating grassland management in
ORCHIDEE: model description and evaluation at 11 eddycovariance sites in Europe, Geosci. Model Dev., 6, 2165-2181, https://doi.org/10.5194/gmd-6-2165-2013, 2013.

COMIFER: Teneur en $\mathrm{P}, \mathrm{K}$ et $\mathrm{Mg}$ des organes végétaux récoltés pour les cultures de plein champ et les principaux fourrages, Comité Français d'Étude et de Développement de la Fertilisation Raisonneé, Paris, 2007 (in French).

Cordell, D., Drangert, J., and White, S.: The story of phosphorus: global food security and food for thought, Global Environ. Chang., 19, 292-305, 2009.

Cordell, D., Neset, T. S., and Prior, T.: The phosphorus mass balance: identifying "hotspots" in the food system as a roadmap to phosphorus security, Curr. Opin. Biotech., 23, 839-845, 2012.

Cordell, D., Jackson, M., and White, S.: Phosphorus flows through the Australian food system: identifying intervention points as a roadmap to phosphorus security, Environ. Sci. Policy, 29, 87$102,2013$.

Dalin, C., Hanasaki, N., Qiu, H., Mauzerall, D. L., and RodriguezIturbe, I.: Water resources transfers through Chinese interprovincial and foreign food trade, P. Natl. Acad. Sci. USA, 111, 97749779, 2014.

Elser, J. and Bennett, E.: Phosphorus cycle: a broken biogeochemical cycle, Nature, 478, 29-31, 2011.

FAO: Fertilizer Use by Crop (5th Edition), Food and Agriculture Organization of the United Nations, Rome, 2012.

Foley, J. A., Ramankutty, N., Brauman, K. A., Cassidy, E. S., Gerber, J. S., Johnston, M., Muller, N. D., O'Connell, C., Ray, D. K., West, P. C., Balzer, C., Bennett, E. M., Carpenter, S. R., Hill, J., Monfreda, C., Polasky, S., Rockström, J., Sheehan, J., Siebert, S., Tilman, D., and Balzer, C.: Solutions for a cultivated planet, Nature, 478, 337-342, 2011.

Grote, U., Craswell, E., and Vlek, P.: Nutrient flows in international trade: ecology and policy issues, Environ. Sci. Policy, 8, 439451, 2005.

Herrero, M., Havlík, P., Valin, H., Notenbaert, A., Rufino, M. C., Thornton, P. K., Blümmelb, M., Weissc, F., Grace, D., and Obersteiner, M.: Biomass use, production, feed efficiencies, and greenhouse gas emissions from global livestock systems, P. Natl. Acad. Sci. USA, 110, 20888-20893, 2013.

Levington Agriculture: A Report for the European Fertiliser Manufacturers' Association. Levington Agriculture Ltd., Ipswich, UK, 1997.

Li, J.: The development and prospective of nutrition in livestock bones, Meat Ind., 322, 41-44, 2008 (in Chinese).

Liu, Y., Villalba, G., Ayres, R. U., and Schroder, H.: Global phosphorus flows and environmental impacts from a consumption perspective, J. Ind. Ecol., 12, 229-247, 2008.

Ma, W., Ma, L., Li, J., Wang, F., Sisák, I., and Zhang, F.: Phosphorus flows and use efficiencies in production and consumption of wheat, rice, and maize in China, Chemosphere, 84, 814-821, 2011.

MacDonald, G. K., Bennett, E. M., Potter, P. A., and Ramankutty, N.: Agronomic phosphorus imbalances across the world's croplands, P. Natl. Acad. Sci. USA, 108, 3086-3091, 2011.

Metson, G. S., Bennett, E. M., and Elser, J. J.: The role of diet in phosphorus demand, Environ. Res. Lett., 7, 044043, https://doi.org/10.1088/1748-9326/7/4/044043, 2012. 
MWPS-18: Livestock Waste Facilities Handbook, Midwest Plan Service, University of Missouri, Ames, IA, USA, 1985.

Obersteiner, M., Peñuelas, J., Ciais, P., Van Der Velde, M., and Janssens, I. A.: The phosphorus trilemma, Nat. Geosci., 6, 897898, 2013

OECD: Secretariat National Soil Surface Nutrient Balances, 1985 to 1995. Explanatory Notes. Coefficients to Convert Livestock Numbers Into Manure Nitrogen Quantities From National Sources, Organisation for Economic Cooperation and Development, Paris, 1991.

Ott, C. and Rechberger, H.: The European phosphorus balance, Resour. Conserv. Recy., 60, 159-172, 2012.

Penuelas, J., Poulter, B., Sardans, J., Ciais, P., Van Der Velde, M., Bopp, L., Boucher, O., Godderis, Y., Hinsinger, P., Llusia, J., Nardin, E., Vicca, S., Obersteiner, M., and Nardin, E.: Humaninduced nitrogen-phosphorus imbalances alter natural and managed ecosystems across the globe, Nat. Commun., 4, 2934, https://doi.org/10.1088/1748-9326/7/4/044043, 2013.

Potter, P., Ramankutty, N., Bennett, E. M., and Donner, S. D.: Characterizing the spatial patterns of global fertilizer application and manure production, Earth Interact., 14, 1-22, 2010.

Quinton, J. N., Govers, G., Van Oost, K., and Bardgett, R. D.: The impact of agricultural soil erosion on biogeochemical cycling, Nat. Geosci., 3, 311-314, 2010.

Ringeval, B., Nowak, B., Nesme, T., Delmas, M., and Pellerin, S.: Contribution of anthropogenic phosphorus to agricultural soil fertility and food production, Global Biogeochem. Cy., 28, 743 756, 2014

Sattari, S. Z., Bouwman, A. F., Giller, K. E., and van Ittersum, M. K.: Residual soil phosphorus as the missing piece in the global phosphorus crisis puzzle, P. Natl. Acad. Sci. USA, 109, 6348-6353, 2012.

Schipanski, M. E. and Bennett, E. M.: The influence of agricultural trade and livestock production on the global phosphorus cycle, Ecosystems, 15, 256-268, 2012.

Scholz, R. W., Ulrich, A. E., Eilittä, M., and Roy, A.: Sustainable use of phosphorus: a finite resource, Sci. Total Environ., 461, 799-803, 2013.

Senthilkumar, K., Nesme, T., Mollier, A., and Pellerin, S.: Regionalscale phosphorus flows and budgets within France: the importance of agricultural production systems, Nutr. Cycl. Agroecosys., 92, 145-159, 2012.

Sheldrick, W., Syers, J. K., and Lingard, J.: Contribution of livestock excreta to nutrient balances, Nutr. Cycl. Agroecosys., 66, 119-131, 2003.
Smil, V.: Phosphorus in the environment: natural flows and human interferences, Annu. Rev. Mater. Sci., 25, 53-88, 2000.

Steffen, W., Richardson, K., Rockström, J., Cornell, S. E., Fetzer, I., Bennett, E. M., Biggs, R., Carpenter, S. R., de Vries, W., de Wit, C. A., Folke, C., Gerten, D., Heinke, J., Mace, G. M., Persson, L. M., Ramanathan, V., Reyers, B., and Sörlin, S.: Planetary boundaries: guiding human development on a changing planet, Science, 347, 1259855, https://doi.org/10.1126/science.1259855, 2015.

Suh, S. and Yee, S.: Phosphorus use-efficiency of agriculture and food system in the US, Chemosphere, 84, 806-813, 2011.

USDA-NRCS: Crop Nutrient Tool: Nutrient Content of Crops. United States Department of Agriculture, Natural Resource Conservation Service, Washington, 2009.

van Dijk, K. C., Lesschen, J. P., and Oenema, O.: Phosphorus flows and balances of the European Union Member States, Sci. Total Environ., 542, 1078-1093, 2016.

Van Vuuren, D. P., Bouwman, A. F., and Beusen, A. H. W.: Phosphorus demand for the 1970-2100 period: a scenario analysis of resource depletion, Global Environ. Chang., 20, 428-439, 2010.

Waller, J. C.: Byproducts and unusual feedstuffs, Feedstuffs, 9, 1822, 2010.

Wang, R., Tao, S., Balkanski, Y., Ciais, P., Boucher, O., Liu, J., Piao, S., Shen, H., Vuoloc, M. R., Valarie, M., Chen, H., Chen, Y., Cozic, A., Huang, Y., Li, B., Li, W., Shen, G., Wang, B., and Zhang, Y.: Exposure to ambient black carbon derived from a unique inventory and high-resolution model, P. Natl. Acad. Sci. USA, 111, 2459-2463, 2014.

Wang, R., Balkanski, Y., Boucher, O., Ciais, P., Peñuelas, J., and Tao, S.: Significant contribution of combustion-related emissions to the atmospheric phosphorus budget, Nat. Geosci., 8, 48-54, 2015.

Wu, H., Yuan, Z., Zhang, Y., Gao, L., and Liu, S.: Life-cycle phosphorus use efficiency of the farming system in Anhui Province, Central China, Resour. Conserv. Recy., 83, 1-14, 2014.

Wu, L. and Ma, M.: The comprehensive utilization of animals' bone in China, Modern Food Sci. Tech., 83, 38-46, 2005 (in Chinese)

Xu, J., Liu, X., Wang, F., Zhang, F., Ma, W., and Ma, L.: Phosphorus balance and environmental effect of animal production in China, Acta Ecol. Sinica, 11, 2911-2918, 2005 (in Chinese). 